\title{
CROSS BORDER PORTFOLIO INVESTMENT AND THE VOLATILITY OF STOCK MARKET INDEX AND RUPIAH'S RATE
}

\author{
Al Muntasir ${ }^{1}$
}

\begin{abstract}
This paper use daily data during the period 2010-2014 to analyse the impact of foreign capital inflows on capital market volatility and on the volatility of Rupiah's rate. The results shows the flow of foreign capital positively affect the Jakarta Composite Index (JCI) but not the rate of Rupiah. Using Vector Error Correction Model, this paper finds a cointegrated and dynamic relationship between the changes in foreign capital flow in Indonesia, with the JCl and the exchange rate of Rupiah against USD. Changes in the Rupiah's rate significantly affect the foreign capital flow and the JCl, while the JCl does not significantly affect the flow of foreign capital and the changes of Rupiah's rate.
\end{abstract}

Keywords: Foreign Capital Flows, Capital Market of Volatility, Currency Exchange JEL Classification: F330, G100, G120

1 Author is student at Postgraduate Program on Management, Department of Economic and Bussiness, University of Gadjah Mada; al_muntasir@ymail.com. 


\section{PENDAHULUAN}

Aliran modal asing dalam bentuk portfolio investment merupakan salah satu topik penting yang banyak diperbincangkan dalam sistem keuangan internasional, khususnya bagi emerging market yang sangat membutuhkan mobilisasi dana asing untuk membiayai program-program pembangunan nasionalnya. Meskipun diyakini bahwa mobilisasi dana asing yang mengalir melalui investasi portofolio akan berdampak positif bagi perekonomian nasional suatu negara (negara tujuan investor asing), khususnya di sektor pasar modal, namun juga dapat menyebabkan extreme volatility bagi pasar modal (Bekaert dan Harvey, 2003; Edwards, 2000) dan akan memengaruhi stabilitas nilai tukar (Chayawadee dan Ho, 2008), yang secara otomatis akan memengaruhi kondisi perekonomian serta iklim investasi di negara yang bersangkutan.

Di Indonesia, aliran modal asing melalui investasi portofolio sudah diperkenankan sejak tahun 1980-an, khususnya pada saat dikeluarkan dan diberlakukannya Keputusan Menteri Keuangan Nomor 1059/KMK/1989, yang secara resmi memperkenankan bagi investor asing untuk menguasai hingga 49\% dari porsi kepemilikannya terhadap efek-efek yang ada di pasar modal Indonesia. Keputusan tersebut merupakan gerbang utama bagi liberalisasi dan integrasi pasar modal Indonesia, yang selanjutnya berkembang hingga diperkenankannya porsi kepemilikan asing hingga mencapai $100 \%$, yaitu tepatnya pada saat diberlakukannya UndangUndang Nomor 8 Tahun 1995 tentang Pasar Modal (UUPM). Dengan diperkenankannya investor asing untuk ikut serta dalam aktivitas perdagangan efek di pasar modal, maka sejak tahun 1989 arus modal asing melalui investasi portofolio mulai mengalir ke Indonesia, dan masuknya aliran modal asing tersebut sangat berdampak positif bagi pertumbuhan dan perkembangan pasar modalnya, yang sebelumnya tersegmentasi dan sempat mengalami kevakuman yang berkepanjangan.

Sejak diberlakukannya keputusan menteri keuangan tersebut, aliran modal asing yang masuk ke Indonesia melalui pasar modal mencapai Rp230,40 milyar atau 23,9\% dari 433 juta saham yang tercatat. Setahun berikutnya (1990), aliran modal asing tersebut meningkat secara signifikan seiiring dengan adanya peningkatan jumlah perusahaan dan saham yang tercatat. Aliran modal asing yang masuk pada tahun 1990 mencapai Rp1.817,52 milyar yang tumbuh hingga $688,85 \%$ dari tahun sebelumnya, dan pertumbuhan ini terus berlangsung secara positif pada tahun-tahun berikutnya.

Masuknya aliran modal asing di atas, secara spontan mendorong pertumbuhan dan perkembangan pasar modal Indonesia, dimana mulai tahun 1989 hingga 1995, Indeks Harga Saham Gabungan (IHSG) rata-rata berada pada level 415,92 dengan rata-rata peningkatannya mencapai 94,57 poin atau tumbuh sebesar 30,99\% per tahun, dan rata-rata nilai kapitalisasi pasarnya mencapai Rp55.021,72 juta atau tumbuh sebesar 216,78\% dengan jumlah perusahaan publik yang listed tumbuh hingga 46,33\% dari 24 perusahaan di tahun 1988 hingga 217 perusahaan di tahun 1994. 
Pertumbuhan dan perkembangan ini sangat signifikan dibandingkan dengan pertumbuhan dan perkembangannya pada masa tersegmentasi dan kevakumannya, dimana rata-rata IHSG hanya berada pada kisaran level 72,94 dengan rata-rata peningkatannya hanya 5,35 poin $(7,75 \%)$ per tahun, dan rata-rata nilai kapitalisasi pasarnya hanya Rp195,5 juta $(4,00 \%)$ dengan jumlah perusahaan publik yang listed hanya 24 perusahaan tanpa mengalami pertumbuhan. Selanjutnya, pada saat diberlakukannya UUPM No. 8 pada tahun 1995 peran investor asing semakin signifikan bagi pertumbuhan dan perkembangan pasar. Rata-rata arus modal asing yang masuk selama periode mencapai Rp41.568,65 miliar atau 41,7\% dari total nilai perdagangannya.

Meningkatnya porsi kepemilkan asing dan arus modal asing yang masuk tersebut semakin mendorong pertumbuhan dan perkembangan pasar, dimana rata-rata IHSG berada pada level 1.645,97 dengan rata-rata peningkatannya mencapai 208,91 poin (19,38\%) per tahun, dengan rata-rata nilai kapitalisasi pasarnya mencapai Rp1.398,613,50 juta (29,27\%), dan jumlah perusahaan publik yang listed meningkat hingga 4,08\% per tahun dari 253 perusahaan (1995) hingga 506 perusahaan (2015). Meskipun aliran modal asing yang masuk selama periode tersebut juga signifikan dan berdampak positif bagi perekembangan pasar modal, namun karena tinggi dan bebasnya arus modal asing yang keluar-masuk juga signifikan menyebabkan extreme volatility bagi pasar modal Indonesia dan diimbangi pula dengan meningkatnya volatilitas nilai tukar Rupiah sebagai akibat dari supply and demand asing dalam transaksi perdagangan efek.

Penarikan dana asing secara tiba-tiba dalam skala yang besar di tahun 1997 akibat goncangan krisis keuangan yang melanda Asia dan contagion effect dari bursa regional mengakibatkan pasar modal Indonesia mengalami keterpurukan yang cukup signifikan, kondisi ini diimbangi pula dengan melemahnya nilai tukar Rupiah terhadap valuta asing, khususnya Dolar Amerika Serikat (IDR/USD). Kondisi ini juga semakin diperburuk akibat adanya perilaku hedging dari investor domestik, yang umumnya mengacu pada perilaku perdagangan asing di masa tersebut.

Pasca pemulihan krisis tersebut, arus modal asing kembali masuk dan relatif lebih tinggi dibandingkan periode-periode sebelumnya, namun kondisi serupa kembali terjadi di tahun 2008 yaitu selama krisis keuangan yang melanda dunia, yang dilanjuti oleh krisis Eropa dan meroketnya harga minyak dunia di tahun 2009. Selanjutnya pasca pemulihan krisis finansial global dan didukung oleh stabilitas serta fundamental perekonomian yang kuat (tahun 2010 - 2014), arus modal asing kembali berperan di Indonesia. Namun aliran modal asing selama periode tersebut terlihat ekstrim dan sangat fluktuatif jika dibandingkan dengan periode-periode sebelumnya. Rata-rata aliran modal asing yang masuk ke Indonesia mencapai Rp4.700,79 miliar dan capital outflow sebanyak Rp4.097,09 miliar per hari. 
Secara umum, dalam beberapa periode juga terlihat bahwa masuknya modal asing ini diikuti dengan penurunan IHSG dan melemahnya nilai tukar rupiah terhadap beberapa valuta asing, khususnya USD, dan arus modal yang keluar selama periode tersebut juga tidak sepenuhnya diimbangi dengan penurunan IHSG dan pelemahan nilai tukar IDR/USD, bahkan dalam beberapa periode juga terlihat arus modal asing yang keluar beriringan dengan peningkatan IHSG dan kurs IDR/USD. Fenomena ini cenderung berlawanan dengan kondisi yang terjadi pada periode-periode sebelumnya, dimana secara umum foreign capital flow cenderung bergerak searah dengan pergerakan IHSG dan kurs IDR/USD. Disamping itu, kondisi ini juga kontras dengan berbagai kajian teoritis, khususnya penjelasan teori portfolio-balance dan good market approach.

Namun demikian, fenomena di atas tampak sejalan dengan hasil kajian Sourionis (2003), yang tidak menemukan hubungan yang dinamis antar variabel tersebut. Artinya, mungkin saja dalam jangka pendek variabel-variabel tersebut tidak memiliki pola pergerakan yang sama, namun dalam jangka panjang cenderung saling menyesuaikan antara satu sama lainnya, atau sejalan dengan hasil penelitian Hau dan Rey (2004) yang menemukan hubungan negatif antara net equity flows dan market return. Dimana hasil penemuan tersebut dihipotesiskan sebagai perilaku portfolio rebalancing, yaitu investor merealokasi dana dari aset-aset yang telah terapresiasi (dikarenakan harga naik) kepada aset yang telah terdepresiasi dengan tujuan melakukan optimalisasi portofolio balance. Disamping itu, terkait dengan hubungan antara indeks saham dan nilai tukar, terdapat pula hasil penelitian yang tidak menunjukkan adanya hubungan interaksi yang signifikan antar kedua (seperti Jorion, 1990; Jorion, 1991; Bodnar dan Gentry, 1993). Sedangkan hasil kajian Evan dan Lyons (2002), Froot dan Ramadorai (2002) menunjukkan bahwa kurs order flows memberikan dampak yang signifikan terhadap nilai tukar, tetapi hanya dalam jangka pendek.

Penelitian ini bertujuan untuk menganalisis dampak perubahan aliran modal asing yang diproksikan dengan Net Foreign Purchase (NFP) terhadap volatilitas pasar modal (diproksikan dengan IHSG) dan nilai tukar (IDR/USD). Analisis perubahan aliran modal asing terhadap kedua variabel tersebut dilakukan dengan pendekatan Vector Auto Regression (VAR) dan Vector Error Correlation Model (VECM), sehingga dengan pendekatan tersebut juga dapat digunakan untuk menguji hubungan antar ketiga variabel, baik hubungan kointegrasi, kausalitas, dan dinamis.

Bagian kedua dari paper ini menguraikan teori dan literatur yang terkait. Bagian ketiga menjelasakan data dan metodologi yang digunakan, sementara bagian keempat menyajikan hasil perhitungan dan analisis. Bagian kelima menguraikan kesimpulan dan menjadi penutup dari paper ini. 


\section{TEORI}

Aliran modal dalam konteks investasi portofolio merupakan salah satu topik penting yang paling banyak diperbincangkan dalam sistem keuangan internasional, khususnya bagi negaranegara berkembang seperti Indonesia karena selalu melibatkan trade-off bagi negara tujuan. Disatu sisi, masuknya dana asing (pembelian asing) dapat meningkatkan modal bagi perusahaanperusahaan di negara tujuan (Todaro \& Smith, 2004) dan dapat meningkatkan kapitalisasi serta membantu mengembangkan efisiensi pasar modal domestik, membantu pasar modal domestik melalui instrumen-instrumen dan teknologi yang lebih canggih yang diperkenalkan investor asing dalam pengelolaan portofolio, dan dapat membantu memperkuat pasar modal domestik dan meningkatkan fungsi otoritas moneter di negara tersebut (Evans, 2002), dapat menambah tabungan domestik, meningkatkan alokasi modal menjadi lebih efisien, dan dapat membawa dampak kepada ekonomi melalui pasar modal seperti kenaikan harga saham dan mendorong perkembangan pasar modal domestik (Bapepam-LK, 2008).

Pada sisi lain, emerging market yang terlalu mengandalkan aliran modal dari investasi portofolio untuk menutupi kelemahan-kelemahan dasar struktural dibidang ekonominya harus menanggung konsekuensi negatif dalam jangka panjang, dimana para investor asing tidak memiliki kepedulian terhadap kepentingan pembangunan di negara tujuan investasi mereka (Todaro dan Smith, 2004), sehingga investasi portofolio dapat menyebabkan extreme volatility bagi pasar modal (Bekaert \& Harvey, 2000) dan akan mempengaruhi nilai tukar (Chayawadee \& Corrine, 2008). Penarikan dana asing (penjualan asing) akan menyebabkan indeks pasar saham mengalami penurunan yang diimbangi dengan meningkatnya permintaan mata uang asing sehingga akan menyebabkan depresiasi bagi mata uang domestik. Beberapa studi juga telah menemukan bahwa perubahan aliran modal asing memiliki hubungan dengan volatilitas pasar modal atau indeks harga saham (Parthapratim Pal, 2008; Frensidy, 2008; Wang, 2007; Richard, 2005; Ibrahim, 2000; Bohn \& Tesar, 1996; Froot \& Donohue, 2002; Karolyi, 2002; Chayawadee \& Corinne, 2008) dan fluktuasi nilai tukar (Chai-anant, 2003; Karolyi, 2002; Brennan \& Cao, 1997), dimana perubahan tersebut akan mempengaruhi permintaan dan penawaran mata uang yang selanjutnya mempengaruhi volatililitas indeks saham. Disamping itu, hasil penelitian Brennan dan Cao (1997), Karolyi (2002), dan Chai-anant (2003) juga menemukan adanya hubungan dinamis antara capital flows dan nilai tukar, namun Souriounis (2003) tidak menemukan hubungan yang dinamis antar keduanya. Sedangkan hasil kajian Evan (2002), Froot dan Ramadorai (2002) menunjukkan bahwa kurs order flows memberikan dampak yang signifikan terhadap nilai tukar, tetapi hanya dalam jangka pendek.

Selain memiliki hubungan kointegrasi dan dinamis dengan aliran modal investasi portofolio, kurs dan harga saham juga memiliki hubungan yang saling mempengaruhi satu sama lainnya. Ada dua pendekatan teori yang dapat menjelaskan hubungan antara nilai tukar dan harga saham, yaitu good market approach dan portfolio balance approach. Good market approach menjelaskan bahwa perubahan nilai tukar akan mempengaruhi competitiveness perusahaan, 
yang selanjutnya akan mempengaruhi pendapatan perusahaan dan selanjutnya harga sahamnya (Dornbusch \& Fischer, 1980). Sedangkan portofolio balance approach menjelaskan bahwa rising stock market akan menarik capital flow yang selanjutnya akan meningkatkan permintaan mata uang domestik dan menyebabkan nilai tukar mata uang domestik terapresiasi (Franke, 1993). Berkaitan dengan hal ini, apakah harga saham menyebabkan volatilitas nilai tukar atau nilai tukar yang menyebabkan volatilitas return saham, tergantung pada situasi negara yang bersangkutan dan time dependent (Ramasamy \& Mathew, 2001). Meskipun secara teoritis terdapat hubungan kausalitas antara nilai tukar dan harga saham, namun bukti empiris menunjukkan bahwa hubungan yang lemah diantara keduanya pada tatanan mikro.

Berberapa studi telah menunjukkan bahwa kurs mempengaruhi harga saham (Ma \& Kao, 1990; Abdalla \& Murinde, 1997; Wongbangpo \& Sharma, 2002). Hasil penelitian tersebut sejalan dengan hasil kajian Bohn dan Tesar (1996) dan Bekaert (2002) yang didukung oleh hasil penelitian Froot (2001), Griffin (2002), Richards (2005), Karolyi (2002), Bonser-Neal (2002), yang juga menemukan hubungan positif antara equity flows dan market return, dimana equity flows cenderung masuk ke pasar dengan diikuti oleh kenaikan market return dan equity keluar dari pasar diikuti oleh penurunan market return. Hubungan positif ini selalu dihipotesiskan sebagai return chasing, trend chasing, atau momentum trading. Akan tetapi, Hau dan Rey (2004) menemukan hubungan yang negatif antara net equity flows dan market return, yang dihipotesiskan sebagai perilaku portfolio rebalancing, yaitu investor merealokasi dana dari asetaset yang telah terapresiasi (dikarenakan harga naik atau currency gains) kepada aset yang telah terdepresiasi dengan tujuan melakukan optimalisasi portfolio balance.

Hasil kajian empiris juga menunjukkan bahwa bagi perusahaan Amerika Serikat (Jorion, 1990, 1991) dan Jepang (Bodnar \& Gentry, 1993) tidak ditemukan hubungan yang signifikan antara nilai tukar dan harga saham. Namun, He dan Ng (1998) menemukan bahwa hanya 25\% dari 171 perusahaan multinasional Jepang yang memiliki eksposur nilai tukar yang signifikan terhadap return saham. Pada tatanan makro, apresiasi mata uang secara negatif mempengaruhi pasar modal domestik yang negaranya sebagai export dominant dan akan berpengaruh positif terhadap pasar modal domestik bagi negara yang import dominant (Ma \& Kao, 1990), sehingga hal ini konsisten dengan goods market approach. Disamping itu, hasil kajian Ajayi dan Mougoue (1996) terhadap delapan negara menunjukkan, bahwa terdapat interaksi yang signifikan antara nilai tukar dan pasar modal, sementara Abdalla dan Murinde (1997) menunjukkan bahwa nilai tukar cenderung berhubungan dengan harga saham.

Hasil studi Bapepam-LK (2008) di Indonesia menunjukkan bahwa terdapat hubungan kointegrasi antara aliran modal asing, volatilitas pasar modal, dan nilai tukar, namun volatilias pasar modal (IHSG) lebih mampu menjelaskan pengaruhnya terhadap perubahan aliran modal asing tetapi tidak mampu menjelaskan pengaruhnya terhadap perubahan nilai tukar (IDR/USD), sedangkan aliran modal asing hanya mampu menjelaskan pengaruhnya terhadap perubahan nilai tukar. Adapun perubahan nilai tukar tidak mampu menjelaskan pengaruhnya terhadap volatilitas IHSG dan nilai tukar. 


\section{METODOLOGI}

\subsection{Jenis dan Sumber Data}

Data sekunder yang digunakan adalah time-series harian selama lima tahun pengamatan (Januari 2010 - Desember 2014), mencakup net foreign purchase dan harga penutupan IHSG (diperoleh dari publikasi Bursa Efek Indonesia), serta kurs tengah Rupiah terhadap Dolar Amerika Serikat (diperoleh dari publikasi Bank Indonesia). Net Foreign Purchase (NFP) digunakan sebagai proksi perubahan aliran modal asing di pasar modal Indonesia, dimana NFP positif menunjukkan adanya aliran modal asing yang masuk dan NFP negatif menunjukkan aliran modal yang keluar, dan dalam hal ini NFP dinyatakan dalam rasio pertumbuhan. Sedangkan pergerakan IHSG digunakan sebagai proksi volatilitas pasar modal Indonesia yang dinyatakan dalam pertumbuhan. Adapun perubahan kurs IDR/USD digunakan sebagai proksi nilai tukar Rupiah terhadap valuta asing yang juga dinyatakan dalam rasio pertumbuhan.

\subsection{Model Empiris}

Metode analisis data dilakukan dengan pendekatan multivariate Vector Auto Regression (VAR) atau Vector Error Correlation Model (VECM), yang dibantu oleh program Eviews 8. Secara sistematis, model dasar VAR adalah, sebagai berikut:

$$
Y_{t}=A_{0}+A_{1} Y_{t-1}+A_{2} Y_{t-2}+\cdots+A_{p} Y_{t-p}+\varepsilon_{t}
$$

dimana $Y_{t}$ adalah vektor $(n x l)$ yang berisi dari masing-masing variabel dalam VAR, $A_{0}$ adalah vektor $(n x l)$ intersep, $A_{l, 2, p}$ adalah koefisien matrik ( $\left.n x n\right)$, dan $\varepsilon_{t}$ adalah vektor $(n x l)$ dari error term.

Berdasarkan bentuk umum di atas, maka model VAR yang diaplikasikan dalam penelitian ini dapat ditulis, sebagai berikut:

$$
\begin{aligned}
N F P_{t} & =\alpha_{10}+\sum_{i=1}^{k} \alpha_{11, i} N F P_{t-i}+\sum_{i=1}^{k} \alpha_{12, i} I H S G_{i-t}+\sum_{i=1}^{k} \alpha_{13, i} K U R S_{i-t}+\varepsilon_{1, t} \\
I H S G_{t} & =\alpha_{20}+\sum_{i=1}^{k} \alpha_{21, i} N F P_{t-i}+\sum_{i=1}^{k} \alpha_{22, i} I H S G_{t-1}+\sum_{i=1}^{k} \alpha_{23, i} K U R S_{i-t}+\varepsilon_{2, t} \\
K U R S_{t} & =\alpha_{30}+\sum_{i=1}^{k} \alpha_{31, i} N F P_{t-1}+\sum_{i=1}^{k} \alpha_{32, i} I H S G_{t-1}+\sum_{i=1}^{k} \alpha_{33, i} K U R S_{i-t}+\varepsilon_{3, t}
\end{aligned}
$$


dimana NFP adalah perubahan aliran modal asing (net foreign purchase), IHSG adalah volatilitas pasar modal atau perubahan IHSG, KURS adalah perubahan atau pertumbuhan nilai tukar Rupiah terhadap Dolar AS, $\alpha$ konstanta, dan $\varepsilon$ adalah error term.

Bentuk VAR diatas merupakan bentuk VAR biasa yang digunakan jika data stasioner pada level. Variansi bentuk VAR biasanya terjadi akibat adanya perbedaan derajat integrasi data pada variabelnya, yang dikenal dengan nama VAR in level dan VAR in difference. VAR level digunakan ketika data penelitian memiliki bentuk stasioner dalam level. Jika data tidak stasioner dalam level, namun tidak memiliki hubungan kointegrasi, maka estimasi VAR dilakukan dalam bentuk difference.

VECM merupakan bentuk VAR yang terestriksi karena keberadaan bentuk data yang tidak stasioner namun terkointegrasi. VECM sering disebut sebagai desain VAR bagi series nonstationer yang memiliki hubungan kointegrasi. Spesifikasi VECM merestriksi hubungan jangka panjang variabel-variabel endogen agar konvergen kedalam hubungan kointegrasinya, namun tetap membiarkan keberadaan dinamisasi jangka pendek. Secara sistematis, model VECM yang diaplikasikan dalam penelitian ini dapat ditulis, sebagai berikut:

$$
\begin{aligned}
& N F P_{t-1}=\alpha_{10} \sum_{i=1}^{1} \alpha_{11} I H S G_{t-1}+\sum_{i=1}^{1} \alpha_{12} K U R S_{t-1}+\varepsilon_{t} \\
& I H S G_{t-1}=\alpha_{20} \sum_{i=1}^{1} \alpha_{21} N F P_{t-1}+\sum_{i=1}^{1} \alpha_{22} K U R S_{t-1}+\varepsilon_{t} \\
& K U R S_{t-1}=\alpha_{30} \sum_{i=1}^{1} \alpha_{31} N F P_{t-1}+\sum_{i=1}^{1} \alpha_{32} I H S G_{t-1}+\varepsilon_{t}
\end{aligned}
$$

Analisis data dengan pendekatan VAR, khususnya VECM mencakup tiga alat analisis utama, yaitu Granger Causality Test, Impulse Response Function, dan Variance Decomposition. Uji kausalitas dilakukan untuk mengetahui apakah suatu variabel endogen dapat diperlakukan sebagai variabel eksogen. Hal ini bermula dari ketidaktahuan kepengaruhan antar variabel. Sedangkan analisis impulse response function bertujuan untuk menguji perilaku dinamis dari model VECM, yang dapat dilihat melalui respon dari setiap variabel terhadap kejutan dari variabel tersebut maupun terhadap variabel endogen lainnya. Adapun analisis variance docomposition bertujuan untuk menguji karakteristik dari model yang digunakan, yaitu seberapa besar perbedaan antara variance sebelum dan sesudah shock, baik shock yang berasal dari diri sendiri maupun shock dari variabel lain untuk melihat pengaruh relatif variabel-variabel penelitian terhadap variabel lainnya. Prosedur variance decomposition yaitu dengan mengukur persentase kejutan-kejutan atas masing-masing variabel. Secara khusus, analisis impulse response dan variance decomposition dalam penelitian ini ditukan untuk mengalisis dampak perubahan aliran modal asing yang keluar dan masuk di pasar modal Indonesia terhadap volatilitasnya. 


\section{HASIL DAN ANALISIS}

Analisis data dilakukan dengan pendekatan Vector Auto Regression (VAR) atau Vector Error Correlation Model (VECM), namun karena data-data yang digunakan bersifat time-series dalam jumlah yang sangat banyak (1,224 series), maka diperlukan sejumlah analisis dasar terhadap data-data tersebut tersebut. Analisis time-series dalam penelitian ini secara berturutturut adalah unit root test, penentuan panjang lag optimal, dan uji kointegrasi. Semua analisis awal ini ditujukan untuk menguji apakah data-data yang digunakan dalam penelitian ini baik digunakan untuk proses estimasi (VAR dan VECM) atau tidak. Adapun hasil uji stasioneritas data dalam penelitian ini terlihat pada Tabel 1, berikut:

\begin{tabular}{|c|c|c|c|c|c|c|}
\hline \multicolumn{7}{|c|}{$\begin{array}{c}\text { Tabel } 1 . \\
\text { Hasil Uji Akar Unit (Uji Stasioner pada Level) }\end{array}$} \\
\hline & \multicolumn{2}{|c|}{ NFP } & \multicolumn{2}{|c|}{ IHSG } & \multicolumn{2}{|c|}{ KURS } \\
\hline & t-Statistic & Prob. & t-Statistic & Prob. & t-Statistic & Prob. \\
\hline ADF test statistic & -19.77821 & 0.0000 & -1.715224 & 0.4233 & 0.946996 & 0.9961 \\
\hline \multicolumn{7}{|l|}{ Test critical value: } \\
\hline $1 \%$ level & -3.435488 & & -3.435497 & & -3.435484 & \\
\hline $5 \%$ level & -2.863697 & & -2.863700 & & -2.863695 & \\
\hline $10 \%$ level & -2.567968 & & -2.567970 & & -2.567967 & \\
\hline
\end{tabular}

Dari Tabel 1 di atas terlihat, bahwa hanya data-data pada variabel NFP (aliran modal investasi portofolio) yang stasioner pada level sedangkan data-data pada variabel IHSG dan KURS bersifat non-stasioner (mengandung akar unit), oleh karenanya kedua variabel tersebut diperlukan pengujian derajat integrasi (uji stasioner pada first difference) yang dilanjuti dengan uji kointegrasi. Sedangkan NFP sudah dapat digunakan dalam proses estimasi VECM dan VAR. Adapun hasil uji derajat integrasi untuk kedua variabel tersebut terlihat dalam Tabel 2, berikut:

\begin{tabular}{l|r|r|r|r}
\multicolumn{5}{c}{ Tabel 2. } \\
Hasil Uji Derajat Integrasi (Uji Stasioner pada 1st Level) \\
\cline { 2 - 5 } & \multicolumn{2}{|c|}{ IHSG } & \multicolumn{2}{c}{ KURS } \\
\cline { 2 - 5 } & t-Statistic & Prob. & t-Statistic & Prob. \\
\hline ADF test statistic & -22.83159 & 0.0000 & -35.37245 & 0.0000 \\
\hline Test critical value: & & & & \\
\hline 1\% level & -3.435497 & & -3.435484 & \\
\hline 5\% level & -2.863700 & & -2.863695 & \\
\hline $10 \%$ level & -2.567970 & & -2.567967 & \\
\hline & & & & \\
\hline
\end{tabular}


Dari Tabel 2 terlihat bahwa kedua variabel (IHSG, dan KURS) stasioner pada $1^{\text {st }}$ level (tidak mengandung akar unit). Sebelum dilanjutkan pada uji kointegrasi, terlebih dahulu diperlukan penentuan panjang Lag yang optimal bagi data-data tersebut. Hasil penentuan panjang Lag terlihat pada Tabel 3, berikut:

\begin{tabular}{|c|c|c|c|c|c|c|}
\hline \multicolumn{7}{|c|}{$\begin{array}{c}\text { Tabel } 3 . \\
\text { Hasil Penentuan Panjang Lag }\end{array}$} \\
\hline Lag & LogL & LR & FPE & AIC & sc & $H Q$ \\
\hline 1 & -22626.43 & NA & $3.24 e+12$ & 37.32141 & $37.35925^{\star}$ & 37.33565 \\
\hline 2 & -22602.11 & 48.40959 & $3.16 e+12$ & 37.29614 & 37.37183 & 37.32463 \\
\hline 3 & -22568.87 & 65.97243 & $3.04 e+12$ & 37.25618 & 37.36972 & $37.29893^{*}$ \\
\hline 4 & -22561.59 & 14.42835 & $3.05 e+12$ & 37.25901 & 37.41039 & 37.31600 \\
\hline 5 & -22555.95 & 11.14608 & $3.06 e+12$ & 37.26454 & 37.45377 & 37.33579 \\
\hline 6 & -22548.82 & 14.03303 & $3.07 e+12$ & 37.26764 & 37.49472 & 37.35313 \\
\hline 7 & -22530.66 & 35.69932 & $3.03 e+12$ & 37.25253 & 37.51745 & 37.35227 \\
\hline 8 & -22518.88 & 23.08294 & $3.01 e+12$ & 37.24795 & 37.55073 & 37.36195 \\
\hline 9 & -22509.11 & $19.12348^{*}$ & $3.01 \mathrm{e}+12^{*}$ & $37.24667^{*}$ & 37.58729 & 37.37491 \\
\hline 10 & -22502.73 & 12.42890 & $3.02 e+12$ & 37.25100 & 37.62947 & 37.39349 \\
\hline
\end{tabular}

Berdasarkan hasil analisis terhadap penentuan panjang Lag di atas, terlihat bahwa sebagian besar indikator (LR, FPE, dan AIC) memiliki nilai terkecil pada Lag kesembilan (Lag 9), sehingga Lag 9 tersebut dipilih sebagai lag yang optimal. Setelah mendapatkan Lag optimal, maka dilanjutkan dengan uji kointegrasi. Pada dasarnya, uji ini tidak diperlukan jika data-data stasioner pada Level. Pengujian ini bertujuan untuk menguji apakah data-data yang digunakan menunjukkan atau memiliki trend stochastic yang sama dan selanjutnya memiliki arah pergerakan yang sama dalam jangka panjang. Adapun hasil pengujian kointegrasi terlihat pada Tabel 4, berikut:

\begin{tabular}{|c|c|c|c|c|c|c|c|}
\hline \multicolumn{8}{|c|}{$\begin{array}{l}\text { Tabel } 4 . \\
\text { Hasil Uji Kointegrasi }\end{array}$} \\
\hline \multirow{3}{*}{$\begin{array}{l}\text { Hypothesized } \\
\text { No. of CE(s) }\end{array}$} & \multirow{3}{*}{ Eigenvalue } & \multicolumn{3}{|c|}{ Trace } & \multicolumn{3}{|c|}{ Max-Eigen } \\
\hline & & \multirow{2}{*}{ Statistic } & \multicolumn{2}{|c|}{ Critical Value } & \multirow{2}{*}{ Statistic } & \multicolumn{2}{|c|}{ Critical Value } \\
\hline & & & $5 \%$ & $1 \%$ & & $5 \%$ & $1 \%$ \\
\hline None ** & 0.134680 & 325.3171 & 29.68 & 35.65 & 175.4677 & 20.97 & 25.52 \\
\hline At most 1 & 0.067826 & 149.8493 & 15.41 & 20.04 & 85.19573 & 14.07 & 18.63 \\
\hline At most 2 & 0.051905 & 64.65361 & 3.76 & 6.65 & 64.65361 & 3.76 & 6.65 \\
\hline
\end{tabular}

Hasil pengujian kointegrasi, baik dengan pendekatan Trace maupun Max-Eigen menunjukkan bahwa data-data yang digunakan dalam penelitian ini bersifat kointergrasi, artinya meskipun variabel-variabel yang digunakan non stasioner pada level, namun dalam jangka panjang variabel-variabel tersebut cenderung menuju keseimbangan. Sehingga kombinasi linear 
dari variabel-variabel ini disebut regresi kointegrasi dan parameter-parameter yang dihasilkan dari kombinasi tersebut dapat disebut sebagai cointegrated parameter. Selama periode pengamatan, rata-rata aliran modal investasi portofolio di Indonesia mencapai 1.474,90 miliar per bulan (Rp 67,9 miliar per hari) dengan rata-rata nilai pembelian asing mencapai Rp42.623,48 miliar per bulan (Rp966,23 miliar per hari) dan penjualannya mencapai Rp41.148,56 miliar per bulan (Rp898,34 miliar per hari). Kondisi ini menunjukkan bahwa secara umum dalam periode tersebut terindikasi adanya arus modal masuk (capital inflow) ke Indonesia melalui pasar modalnya. Capital inflow tertinggi terjadi pada April 2011 yang mencapai Rp17.515,00 miliar dengan nilai pembeliannya sebesar Rp42.997,00 miliar dan nilai penjualannya mencapai Rp25.482,00 miliar. Nilai ini meningkat sebesar Rp19.781,00 miliar atau tumbuh secara signifikan yaitu mencapai 872,95\% dari Maret 2011 yang tercatat adanya capital outflow hingga Rp2.266 miliar. Sedangkan capital outflow tertinggi terjadi pada Juni 2013, yang mencapai Rp20.132,0 miliar dengan nilai pembelian asing hanya sebesar Rp63.005 miliar sementara nilai penjualan jauh lebih tinggi yakni mencapai Rp83.137 miliar. Sedangkan untuk Indeks Harga Saham Gabungan (IHSG), rata-rata berada pada level 4.100,75 dengan tingkat pertumbuhannya sebanyak 43,60 poin $(1,26 \%)$ per bulan. Pertumbuhan tertinggi terjadi pada September 2010 yaitu sebanyak 419,42 poin (13,61\%), Februari 2013 sebanyak 419,42 poin (7,68\%), dan Juli 2011 sebanyak $242,23(6,23 \%)$. Sedangkan pertumbuhan terendah (penurunannya tertinggi) terjadi pada Agustus 2013 yaitu sebanyak 415,29 poin (-9,01\%), Mei 2012 sebanyak 347,91 poin (-8,32\%), dan Januari 2011 sebanyak 294,34 poin (-7,95\%). Secara umum IHSG tumbuh secara positif setiap bulannya, hal ini menunjukkan bahwa kinerja pasar modal dan iklim investasi serta perekonomian nasional Indonesia semakin baik dari waktu ke waktu. Adapun untuk variabel nilai tukar, rata-rata kurs IDR/USD berada pada level Rp9.942,17 per bulan, yang secara umum tumbuh secara positif sebanyak 50,58 poin per bulannya (0,49\%). Hal ini mengindikasikan bahwa Rupiah cenderung terdepresiasi oleh Dollar AS disetiap bulannya. Dalam periode tersebut, tingkat depresiasi Rupiah tertinggi terjadi pada Agustus 2013 yakni sebanyak 927,00 poin atau 9,04\% dari level Rp10.257,00 ke level Rp11.184,00 selanjutnya pada November 2013 sebanyak 704,00 poin (6,25\%) dari Rp11.273,00 menjadi Rp11.977,00, dan pada September 2014 sebanyak 498,0 poin (4,26\%) dari Rp11.690,00 menjadi Rp12.188,00. Sedangkan tingkat apresiasi Rupiah tertinggi terjadi pada Februari 2014 yakni sebanyak 601,00 poin $(4,92 \%)$ dari Rp12.210,00 menjadi Rp11.609,00, selanjutnya pada Juli 2014 sebanyak 295,00 poin (2,48\%) dari Rp11.875,00 menjadi Rp11.580,00, dan Maret 2014 sebanyak 249,00 poin (2,14\%) dari Rp11.609,00 menjadi Rp11.360,00. Dengan demikian, meskipun dalam jangka pendek ketiga variabel memiliki pola pergerakan yang sangat bervariasi, namun dalam jangka panjang ketiganya menunjukkan trend yang sama. Oleh karena itu, maka hipotesis kedua $\left(\mathrm{H}_{2}\right)$ dalam penelitian ini didukung, artinya perubahan aliran modal asing, volatilitas pasar modal, dan nilai tukar memiliki hubungan kointegrasi antar satu sama lainnya, dan hal ini sejalan dengan sebagian besar hasil penelitian-penelitian sebelumnya, baik di Indonesia sendiri maupun di luar Indonesia sebagaimana yang ditelah disebutkan pada bagian sebelumnya dari penelitian ini. 
Setelah ditemukan adanya hubungan kointegrasi diantara ketiga variabel tersebut, maka data-data dari ketiga variabel tersebut dapat digunakan dalam proses estimasi VECM atau VAR. Hasil estimasi dari pendekatan tersebut dapat dilihat pada lampiran, dan berdasarkan tingkat signifikansi pada masing-masing variabel, maka substitusi hasil estimasi VECM kedalam model VAR dapat disederhanakan menjadi:

$$
\begin{aligned}
\mathrm{D}(\text { IHSG })= & -1.207 *(\operatorname{IHSG}(-1)+0.168 * \mathrm{KURS}(-1)+1.312 * \mathrm{NFP}(-1))+0.234 * \mathrm{D}(\mathrm{IHSG}(1))+ \\
& 0.238 * \mathrm{D}(\mathrm{IHSG}(-2))+0.204 * \mathrm{D}(\mathrm{KURS}(-1))+0.269 * \mathrm{D}(\mathrm{KURS}(-2))+0.256 * \mathrm{D}(\mathrm{KURS}(-3))+ \\
& 0.215 * \mathrm{D}(\mathrm{KURS}(-4))+0.216 * \mathrm{D}(\mathrm{KURS}(-5))+0.167 * \mathrm{D}(\mathrm{KURS}(-6))+0.127 * \mathrm{D}(\mathrm{KURS}(-7)) \\
+ & 0.076 * \mathrm{D}(\mathrm{KURS}(-8))+1.492 * \mathrm{D}(\mathrm{NFP}(1))+1.457 * \mathrm{D}(\mathrm{NFP}(-2))+1.340 * \mathrm{D}(\mathrm{NFP}(-3)) \\
+ & 1.216 * \mathrm{D}(\mathrm{NFP}(-4))+0.923 * \mathrm{D}(\mathrm{NFP}(-5))+0.810 * \mathrm{D}(\mathrm{NFP}(-6))+0.724 * \mathrm{D}(\mathrm{NFP}(-7))+ \\
& 0.242 * \mathrm{D}(\mathrm{NFP}(-8))+0.150 * \mathrm{D}(\mathrm{NFP}(-9)) \\
\mathrm{D}(\mathrm{KURS})= & 0.168 *(\mathrm{KURS}(-1)+1.312 * \mathrm{NFP}(-1))-0.874 * \mathrm{D}(\mathrm{KURS}(-1))-0.767 * \mathrm{D}(\mathrm{KURS}(2))- \\
& 0.672 * \mathrm{D}(\mathrm{KURS}(3))-0.572 * \mathrm{D}(\mathrm{KURS}(-4))-0.526 * \mathrm{D}(\mathrm{KURS}(5))-0.424 * \mathrm{D}(\mathrm{KURS}(-6)) \\
& -0.325 * \mathrm{D}(\mathrm{KURS}(-7))-0.221 * \mathrm{D}(\mathrm{KURS}(-8))-0.123 * \mathrm{D}(\mathrm{KURS}(-9)) \\
= & -0.092 *(\operatorname{IHSG}(-1)+0.168 * \mathrm{KURS}(-1)+1.312 * \mathrm{NFP}(-1))+0.073 * \mathrm{D}(\operatorname{IHSG}(1))- \\
& 0.028 * \mathrm{D}(\mathrm{KURS}(8))-0.030 * \mathrm{D}(\mathrm{KURS}(-9))-0.873 * \mathrm{D}(\mathrm{NFP}(-1))-0.848 * \mathrm{D}(\mathrm{NFP}(-2)) \\
& -0.841 * \mathrm{D}(\mathrm{NFP}(-3))-0.694 * \mathrm{D}(\mathrm{NFP}(-4))-0.574 * \mathrm{D}(\mathrm{NFP}(-5))-0.464 * \mathrm{D}(\mathrm{NFP}(-6))- \\
& 0.336 * \mathrm{D}(\mathrm{NFP}(-7))-0.217 * \mathrm{D}(\mathrm{NFP}(-8))-0.094 * \mathrm{D}(\mathrm{NFP}(-9))
\end{aligned}
$$

Berdasarkan model di atas, terlihat bahwa tidak semua lag signifikan pada masing-masing persamaan, menurut Pyndick dan Rubinfeld (1998) hal ini merupakan tipikal dalam VECM dan VAR. Pada persamaan pertama dengan IHSG sebagai variabel dependen, terlihat bahwa baik dalam jangka pendek maupun jangka panjang pergerakan IHSG sangat berkaitan dengan pergerakan dirinya sendiri, nilai tukar IDR/USD, dan aliran modal asing. Baik dalam jangka pendek maupun jangka panjang, perubahan aliran modal asing memiliki kontribusi terbesar dalam menggerakkan IHSG, hal ini terlihat dari koefisiennya yang rata-rata lebih tinggi dibandingkan koefisien variabel lainnya. Kondisi ini sangat relevan dengan fakta yang terjadi di lapangan, dimana jumlah investor asing masih sangat tinggi di bursa efek Indonesia dan umumnya mereka juga memiliki dana yang lebih besar dibandingkan investor domestik, sehingga aksi beli (jual) mereka secara spontan akan meningkatkan (menurunkan) IHSG. Hal ini sekaligus menunjukkan bahwa pasar saham Indonesia masih memiliki tingkat volatilitas yang tinggi, sehingga sangat rentan terhadap goncangan, baik yang bersumber dari internal maupun eksternal. Sedangkan pada persamaan kedua dengan kurs sebagai variabel dependen, terlihat bahwa dalam jangka pendek perubahan nilai tukar IDR/USD secara positif berkaitan dengan adanya perubahan pada dirinya sendiri dan aliran modal asing yang terjadi pada satu periode sebelumnya, tetapi perubahan tersebut tidak berhubungan dengan pergerakan IHSG. Sedangkan dalam jangka panjang, perubahan nilai tukar IDR/USD sepenuhnya dipengaruhi oleh pergerakannya sendiri secara negatif, hal ini mengindikasikan bahwa dalam jangka panjang perubahannya lebih 
banyak dijelaskan oleh variabel-variabel makro lainnya, seperti ekspor-impor dan pertumbuhan ekonomi. Dalam jangka pendek, perubahan aliran modal asing memiliki kontribusi yang besar dalam menggerakkan supply and demand valuta asing. Adapun pada persamaan ketiga dengan NFP sebagai variabel dependen, terlihat bahwa dalam jangka pendek arus modal asing secara positif berkaitan dengan perubahannya sendiri dan perubahan nilai tukar yang terjadi pada satu periode sebelumnya, tetapi perubahan tersebut berhubungan negatif dengan pergerakan IHSG. Sedangkan dalam jangka panjang, hampir sepenuhnya arus modal asing dipengaruhi oleh perubahannya sendiri.

Hasil estimasi di atas hanya memperlihatkan model atau pola hubungan antar variabel. Pada persamaan-persamaan di atas terlihat, bahwa masing-masing variabel berhubungan satu sama lainnya, namun apakah dalam hubungan tersebut terdapat kekuatan untuk saling mempengaruhinya satu sama lainnya? Untuk menjawab pertanyaan tersebut, maka diperlukan pengujian kausalitas, yang dalam hal ini uji kausalitas dilakukan dengan pendekatan Granger Causality Test, dengan hasil pengujiannya terlihat pada Tabel 5, berikut:

\begin{tabular}{|c|c|c|c|c|c|c|c|c|c|}
\hline \multicolumn{10}{|c|}{$\begin{array}{c}\text { Tabel } 5 . \\
\text { Hasil Pengujian Granger Causality }\end{array}$} \\
\hline \multirow{3}{*}{ Excluded } & \multicolumn{9}{|c|}{ Dependent Variable } \\
\hline & \multicolumn{3}{|c|}{ NFP } & \multicolumn{3}{|c|}{$\mathrm{D}(\mathrm{IHSG})$} & \multicolumn{3}{|c|}{ D(KURS) } \\
\hline & Chi-sq & df & Prob. & Chi-sq & df & Prob. & Chi-sq & df & Prob. \\
\hline $\mathrm{D}(\mathrm{IHSG})$ & 12.59372 & 9 & 0.8119 & - & - & - & - & - & - \\
\hline D(KURS) & 16.74093 & 9 & $0.0529^{*}$ & - & - & - & - & - & - \\
\hline All & 30.50732 & 18 & $0.0328^{* *}$ & - & - & - & - & - & - \\
\hline & & & & & & & & & \\
\hline NFP & - & - & - & 65.82742 & 9 & $0.0000^{\star * *}$ & - & - & - \\
\hline D(KURS) & - & - & - & 129.2951 & 9 & $0.0000^{* * *}$ & - & - & - \\
\hline All & - & - & - & 154.4067 & 18 & $0.0000^{* * *}$ & - & - & - \\
\hline NFP & & - & - & - & - & - & 5418890 & 9 & 07964 \\
\hline $\mathrm{D}(\mathrm{IHSG})$ & - & - & - & - & - & - & 12.18012 & 9 & 0.2033 \\
\hline All & - & - & - & - & - & - & 21.05295 & 18 & 0.2768 \\
\hline
\end{tabular}

Hasil granger causality test menunjukkan bahwa perubahan aliran modal asing di Indonesia, baik yang masuk (capital inflow) maupun keluar (capital outflow) signifikan dipengaruhi oleh perubahan nilai tukar IDR/USD, tetapi tidak signifikan dipengaruhi oleh pergerakan IHSG. Berkaitan dengan hasil estimasi model VECM dan VAR sebelumnya, maka apresiasi Rupiah terhadap Dollar Amerika Serikat mendorong minat investor asing untuk berinvestasi di Indonesia, karena penguatan mata uang domestik juga mengindikasikan bahwa perekonomian nasional yang baik sehingga berdampak positif bagi iklim investasinya. Namun, kinerja pasar modal Indonesia yang ditunjukkan oleh IHSG tidak signifikan mempengaruhi investasi asing, karena mungkin hal ini sudah menjadi karakteristik dari investasi internasional, dimana keputusan 
investasi internasional didasarkan pada korelasi yang rendah antar pasar modal, tetapi bukan berdasarkan kinerja pasar. Sedangkan pergerakan IHSG signifikan dipengaruhi oleh perubahan aliran modal asing dan nilai tukar IDR/USD, artinya selain memiliki hubungan yang kuat dengan perubahan aliran modal asing, setiap kenaikan IHSG juga signifikan disebabkan oleh apresiasi Rupiah (depresiasi Dollar USD) yang terjadi pada periode sebelumnya. Dengan kata lain, setiap terjadi aksi jual dari investor asing (arus jual = capital outflow) dan apresiasi rupiah, maka secara signifikan akan meningkatkan IHSG, sebaliknya aksi beli asing dan depresiasi Rupiah secara signifikan akan menurunkan IHSG. Adapun perubahan nilai tukar IDR/USD tidak signifikan dipengaruhi oleh pergerakan IHSG dan perubahan aliran modal asing, hal ini menunjukkan bahwa perubahan nilai tukar IDR/USD lebih banyak dipengaruhi oleh variabel-variabel makro lainnya.

Dari hasil granger causality test ini juga terlihat bahwa tidak terdapat hubungan kausalitas antara perubahan aliran modal investasi portofolio di Indonesia dengan pergerakan IHSG dan dengan perubahan nilai tukar IDR/USD, serta tidak ditemukan pula hubungan kausalitas antara pergerakan IHSG dan perubahan nilai tukar IDR/USD. Dengan demikian, maka hipotesis ketiga $\left(\mathrm{H}_{3}\right)$ dalam penelitian ini tidak didukung, sehingga konsep good market dan portfolio-balance approach tidak berlaku di Indonesia. Hasil temuan ini juga sejalan dengan beberapa hasil penelitian sebelumnya, baik di Indonesia maupun di luar Indonesia, yang juga tidak ditemukan adanya hubungan kausal diantara ketiga variabel tersebut, namun model dan mekanisme antar hasil penelitian cenderung berbeda-beda sesuai dengan kondisi yang berlaku di negara yang diteliti, dimana beberapa diantaranya menemukan bahwa volatilitas pasar saham mempengaruhi perubahan nilai tukar dan aliran modal asing yang selanjutnya merujuk pada konsep good market approach, namun beberapa lainnya menemukan bahwa perubahan nilai tukar yang mampengaruhi volatilitas pasar modal dan aliran modal yang selanjutnya mengarah pada konsep portfolio-balance approach. Spesifiknya, hasil penelitian ini sejalan dengan hasil kajian Jorion (1990, 1991) di Amerika Serikat dan Bodnar dan Gentry (1993) di Jepang, yang juga menunjukkan bahwa kedua konsep tersebut (good market dan portfolio-balance approach) tidak berlaku di negara tersebut. Secara skematis, hasil analisis terhadap hubungan antar ketiga variabel dalam penelitian ini terlihat pada Gambar 1, berikut:

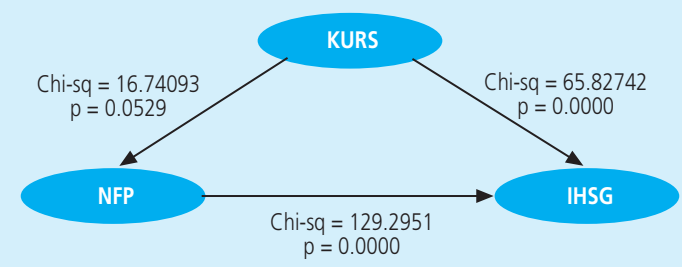

Gambar 1. Hubungan Perubahan Aliran Modal Investasi, Kurs, dan IHSG 
Selanjutnya untuk mengetahui bagaimana pengaruh shock dari suatu variabel terhadap variabel-variabel lain dan berapa lama pengaruh shock tersebut akan diuji melalui pendekatan impuls response function (IRF). Selain dapat mengetahui pengaruh dan lama shock tersebut, pendekatan IRF juga dapat digunakan untuk mengetahui sampai kapan pengaruh shock tersebut akan hilang. Hasil analisis IFR untuk 20 hari terlihat pada Grafik 1. Pada grafik-grafik tersebut, response dari perubahan masing-masing variabel akibat adanya informasi baru diukur dengan 1-standar deviasi. Sumbu vertikal pada grafik tersebut menggambarkan nilai response atau pertumbuhan dari masing-masing variabel, sedangkan sumbu horizontal menggambarkan waktu atau periode setelah terjadinya shock, yang dalam hal ini disajikan untuk 20 perioe kedepan. Pada grafik pertama (kolom pertama dan baris pertama) menggambarkan response pergerakan IHSG terhadap dirinya, dimana setiap IHSG meningkat sebesar 1\%, akan direspon secara positif pada satu periode setelahnya hingga mencapai 1,15\% dan selanjutnya turun dan terus berfluktuasi hingga kembali normal pada periode kedelapan. Dalam waktu yang bersamaan, pergerakan IHSG akan direspon secara positif oleh perubahan nilai tukar IDR/USD dan perubahan aliran modal asing, namun berdasarkan hasil estimasi VECM dan VAR kedua variabel ini tidak signifikan dipengaruhi oleh pergerakan IHSG, sehingga response tersebut dianggap lemah dan tidak menjadi fokus pembahasan dalam paper ini.

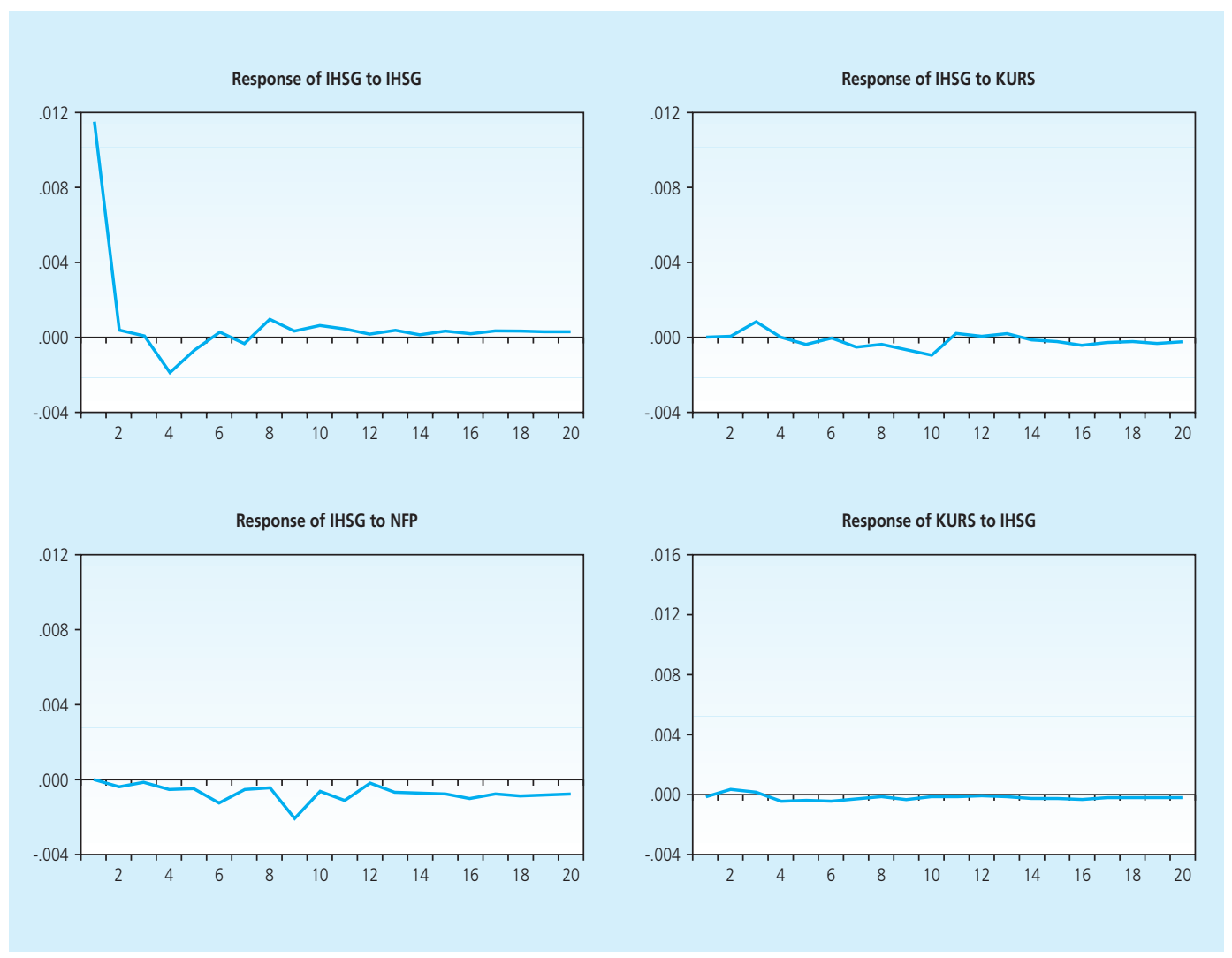



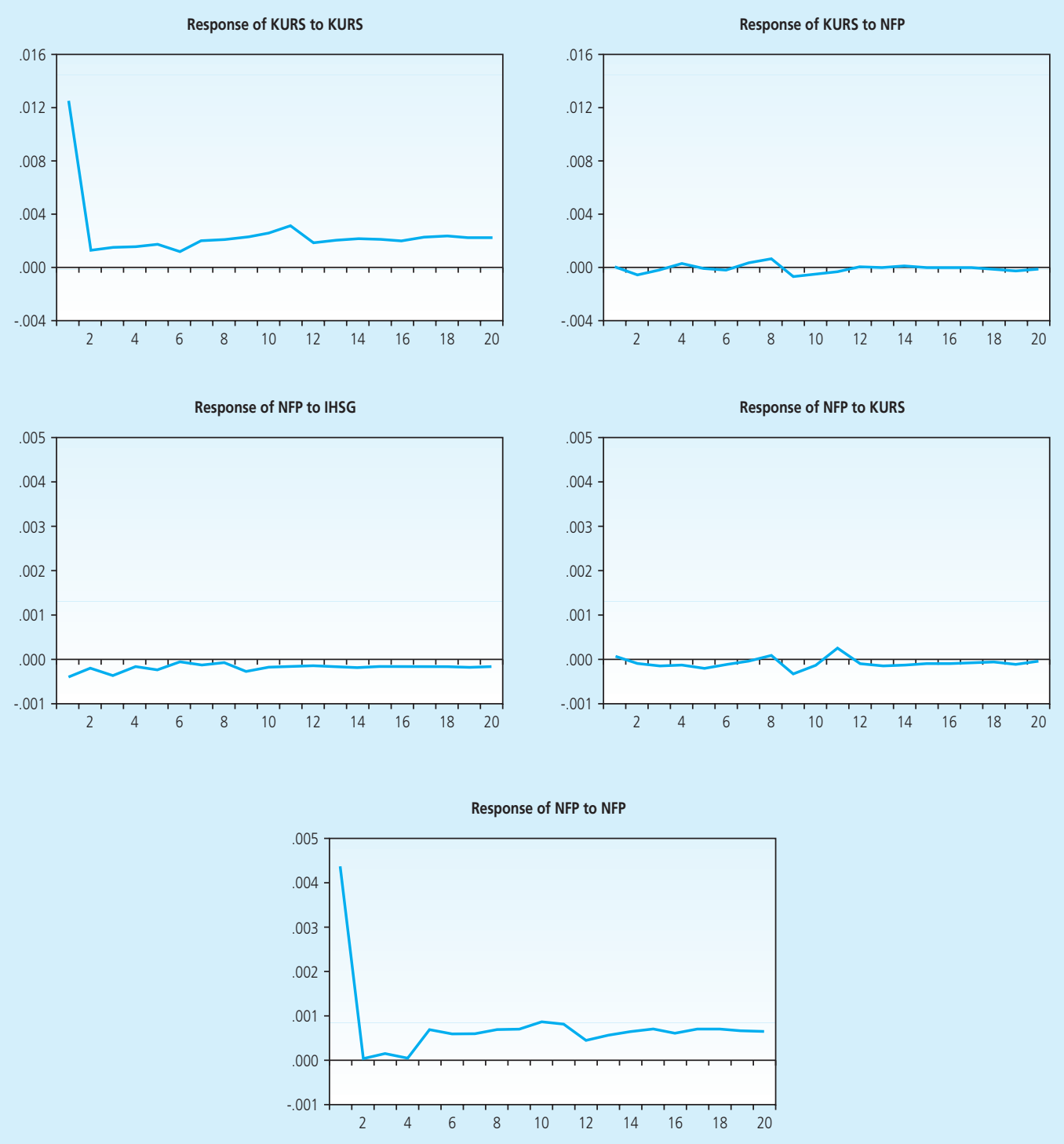

Grafik 1.

Hubungan Dinamis Antara Perubahan NFP, IHSG, dan Kurs selama 20 periode

Pada grafik kedua (baris kedua kolom kedua) menggambarkan response dari perubahan nilai tukar IDR/USD terhadap dirinya sendiri dimana setiap terjadi perubahan nilai tukar IDR/ USD sebanyak $1 \%$, maka akan direspon secara positif pada satu periode setelahnya hingga mencapai 1,26\%, namun pada periode kedua kembali turun dan berfluktuasi hingga normal kembali pada periode keduabelas. Dalam waktu yang bersamaan, setiap terjadi perubahan nilai tukar IDR/USD (depresiasi Rupiah), maka perubahan tersebut akan direspon secara negatif 
oleh investor di pasar modal, dimana kenaikan nilai tukar IDR/USD (depresiasi Rupiah) sebanyak 1\%, akan memicu IHSG turun sebanyak 0,197\% dan akan terus berfluktuasi hingga normal kembali pada periode kedelapan. Kondisi ini mungkin disebabkan oleh adanya peralihan modal investor dari pasar modal ke pasar valuta asing. Disamping itu, perubahan nilai tukar IDR/USD juga akan direspon secara negatif oleh aliran modal asing pada periode kedua setelahnya, dimana kenaikan nilai tukar IDR/USD sebanyak $1 \%$ akan memicu investor asing untuk menarik dananya dari Indonesia atau mengalihkannnya kedalam forex hingga 0,06\% dan akan terus berfluktuasi hingga normal kembali pada periode keduabelas.

Pada grafik ketiga (baris ketiga kolom ketiga) menggambarkan response dari perubahan aliran modal asing terhadap dirinya sendiri, dimana setiap terjadi capital inflow sebanyak $1 \%$, maka akan direspon secara positif pada satu periode setelahnya hingga mencapai 0,4\% kemudian turun dan kembali meningkat pada periode kelima dan kembali normal pada periode keduabelas. Kondisi ini menunjukkan bahwa masuknya modal asing ke Indonesia akan memicu sumber dana asing lainnya untuk masuk juga ke Indonesia, atau keputusan investor asing berinvestasi di Indonesia akan memicu investor asing lainnya untuk berinvestasi di Indonesia pula. Namun hal ini patut diwaspadai jika terjadi fenomena sebaliknya. Dari estimasi ini, juga terindikasi adanya kemungkinan bahwa investor asing di Indonesia cenderung melakukan herding antara satu sama lainnya. Dalam waktu yang bersamaan, perubahan aliran modal asing juga direspon oleh kenaikan IHSG. Masuknya dana asing ke Indonesia mendorong peningkatan IHSG hingga 0,42\% pada satu periode setelahnya dan terus tumbuh hingga normal kembali pada periode kesepuluh. Disamping itu, juga akan direspon oleh perubahan kurs IDR/USD, namun berdasarkan hasil estimasi VECM dan VAR tidak menunjukkan adanya hubungan yang signifika, sehingga response tersebut dianggap lemah dan tidak menjadi fokus pembahasan dalam paper ini.

Selanjutnya setelah menganalisis perilaku dinamis melalui impulse response, selanjutnya akan dilihat karakteristik model melalui variance decomposition. Variance decomposition berguna untuk menyusun forecast error variance suatu variabel, yaitu seberapa besar perbedaan antara variance sebelum dan sesudah shock, baik shock yang berasal dari dirinya sendiri maupun shock yang berasal dari variabel lainnya serta untuk melihat pengaruh relatif setiap variabelvariabel yang diteliti terhadap variabel-variabel lainnya diluar model ini. Adapun hasil analisis variance decomposition dari aliran modal asing (NFP), pergerakan IHSG, dan nilai tukar IDR/ USD selama 20 hari ke depan terlihat pada Tabel 6, berikut: 


\begin{tabular}{|c|c|c|c|c|c|c|c|c|c|}
\hline \multicolumn{10}{|c|}{$\begin{array}{c}\text { Tabel } 6 . \\
\text { Hasil Analisis Variance Decomposition }\end{array}$} \\
\hline \multirow[t]{2}{*}{ Period } & \multicolumn{3}{|c|}{$\begin{array}{l}\text { Perubahan NFP dijelaskan oleh } \\
\text { Kejutan }\end{array}$} & \multicolumn{3}{|c|}{$\begin{array}{l}\text { Pergerakan IHSG dijelaskan oleh } \\
\text { Kejutan }\end{array}$} & \multicolumn{3}{|c|}{$\begin{array}{l}\text { Perubahan KURS dijelaskan oleh } \\
\text { Kejutan }\end{array}$} \\
\hline & IHSG* $^{*}$ & KURS & NFP* & IHSG* & KURS* & NFP* & IHSG & KURS* & NFP \\
\hline 1 & 0.909214 & 0.014713 & 99.07607 & 100.0000 & 0.000000 & 0.000000 & 0.024690 & 99.97531 & 0.000000 \\
\hline 2 & 1.144254 & 0.064238 & 98.79151 & 99.87751 & 0.000221 & 0.122269 & 0.070907 & 99.68062 & 0.248472 \\
\hline 3 & 1.820392 & 0.172526 & 98.00708 & 99.35872 & 0.498503 & 0.142782 & 0.077609 & 99.64088 & 0.281511 \\
\hline 4 & 1.960805 & 0.266727 & 97.77247 & 99.13875 & 0.485597 & 0.375656 & 0.202608 & 99.48808 & 0.309311 \\
\hline 5 & 2.200586 & 0.480806 & 97.31861 & 98.83839 & 0.601513 & 0.560094 & 0.306269 & 99.38447 & 0.309262 \\
\hline 6 & 2.182455 & 0.541451 & 97.27609 & 97.67472 & 0.598644 & 1.726641 & 0.451077 & 99.21497 & 0.333958 \\
\hline 7 & 2.238766 & 0.548516 & 97.21272 & 97.26768 & 0.811497 & 1.920819 & 0.504527 & 99.10730 & 0.388171 \\
\hline 8 & 2.226211 & 0.570760 & 97.20303 & 97.05100 & 0.913555 & 2.035442 & 0.507384 & 98.90581 & 0.586802 \\
\hline 9 & 2.510853 & 1.063140 & 96.42601 & 93.88406 & 1.200426 & 4.915511 & 0.564715 & 98.59627 & 0.839018 \\
\hline 10 & 2.578778 & 1.111903 & 96.30932 & 93.03789 & 1.828686 & 5.133422 & 0.554984 & 98.49112 & 0.953899 \\
\hline 11 & 2.626367 & 1.319774 & 96.05386 & 92.20588 & 1.829117 & 5.965000 & 0.538906 & 98.48539 & 0.975708 \\
\hline 12 & 2.715741 & 1.352218 & 95.93204 & 92.17793 & 1.828369 & 5.993702 & 0.536802 & 98.50381 & 0.959389 \\
\hline 13 & 2.806426 & 1.427985 & 95.76559 & 91.84053 & 1.842892 & 6.316581 & 0.544514 & 98.51514 & 0.940350 \\
\hline 14 & 2.910953 & 1.484295 & 95.60475 & 91.48808 & 1.852009 & 6.659914 & 0.574825 & 98.50032 & 0.924853 \\
\hline 15 & 2.966516 & 1.494257 & 95.53923 & 91.05599 & 1.880931 & 7.063079 & 0.599965 & 98.49244 & 0.907599 \\
\hline 16 & 3.048825 & 1.511045 & 95.44013 & 90.31705 & 1.986929 & 7.696018 & 0.640870 & 98.46475 & 0.894379 \\
\hline 17 & 3.105892 & 1.504270 & 95.38984 & 89.89789 & 2.048126 & 8.053979 & 0.653730 & 98.47166 & 0.874612 \\
\hline 18 & 3.163129 & 1.493071 & 95.34380 & 89.40195 & 2.091798 & 8.506254 & 0.661605 & 98.47391 & 0.864487 \\
\hline 19 & 3.243188 & 1.519820 & 95.23699 & 88.92659 & 2.175298 & 8.898109 & 0.669220 & 98.44622 & 0.884556 \\
\hline 20 & 3.300495 & 1.506730 & 95.19277 & 88.54943 & 2.207759 & 9.242807 & 0.674639 & 98.44517 & 0.880191 \\
\hline
\end{tabular}

Hasil analisis variance decomposition menunjukkan bahwa forecast error variance dari perubahan aliran modal asing (NFP) di Indonesia pada periode pertama, 99,07\% variabilitasnya ditentukan oleh perubahan yang terjadi pada dirinya sendiri dan pada periode berikutnya cenderung menurun meskipun masih dalam level yang tinggi. Disamping itu, sebanyak 0,91\% pada periode pertama dari variabilitas NFP dijelaskan oleh pergerakan IHSG dan hal ini akan terus meningkat hingga mencapai 2,20\% di periode kelima dan 3,30\% di periode keduapuluh setelahnya. Hingga periode ke-20, forcest error variance NFP yang dapat dijelaskan oleh perubahannya sendiri sebesar 95.19\%, hal ini menunjukkan bahwa perubahan aliran modal investasi portofolio di Indonesia, baik masuk maupun keluar lebih banyak dipengaruhi oleh dirinya sendiri (perilaku investor) daripada faktor-faktor lainnya. Sedangkan forecast error varance dari pergerakan IHSG pada periode pertama 100\% variabilitasnya ditentukan oleh perubahannya sendiri, sedangkan perubahan nilai tukar IDR/USD dan perubahan NFP tidak memiliki kontribusi sama sekali pada periode pertama, tetapi pada periode berikutnya variabilitas IHSG mampu dijelaskan oleh perubahan kurs IDR/USD dan perubahan NFP, dan hal ini semakin tinggi hingga sementara kontribusi dari dirinya sendiri semakin berkurang. Jika dibandingkan dengan perubahan kurs IDR/USD, perubahan NFP memiliki kontribusi yang lebih tinggi dalam menjelaskan variabilitas perubahan IHSG. Adapun forecast error variance 
dari perubahan nilai tukar IDR/USD pada periode pertama juga hampir sepenuhnya (99,97\%) dipengaruhi oleh pergerakannya sendiri, sedangkan kontribusi perubahan NFP dan pergerakan IHSG tidak menunjukkan kontribusi yang berarti. Kondisi ini kembali menunjukkan bahwa perubahan kurs IDR/USD lebih banyak dijelaskan oleh variabel-variabel makro dibandingkan dengan IHSG dan NFP.

Berdasarkan hasil analisis impulse response dan impuls decomposition tersebut, jelas terlihat bahwa perubahan aliran modal asing dalam konteks investasi portofolio akan membawa dampak positif dan negatif bagi volatilitas pasar modal. Arus modal asing yang masuk signifikan berdampak positif bagi volatilitas pasar modal Indonesia (mendorong kenaikan IHSG), namun sebaliknya arus modal asing yang keluar juga signifikan berdampak negatif bagi volatilitas pasar modal (penurunan IHSG). Dengan demikian, maka hipotesis pertama $\left(\mathrm{H}_{1}\right)$ dalam penelitian ini didukung. Hal ini sesuai dengan pandangan ekonom mainstream dan para ekonom lainnya, dimana ekonom mainstream menyatakan bahwa aliran modal asing akan membawa dampak positif bagi perekonomian melalui pasar modal dan ekonom lainnya (non-mainstream) menyatakan bahwa aliran modal asing cenderung meningkatkan extreme volatility bagi pasar modal di negara tujuan. Sehingga trade-off ini akan membawa pasar modal Indonesia kepada salah satu wahana investasi yang memiliki prospek bisnis yang semakin menjanjikan diantara pasar-pasar modal lainnya yang ada di dunia serta akan memperbesar peluang bagi kemajuan dan perkembangannya di masa yang akan datang. Hasil analisis impulse response dan variance docomposition juga menunjukkan adanya perilaku dinamis di antara ketiga variabel, sehingga hipotesis keempat $\left(\mathrm{H}_{4}\right)$ juga diterima.

\section{KESIMPULAN}

Hasil penelitian menunjukkan bahwa terdapat hubungan kointegrasi dan dinamis antara perubahan aliran modal asing, pergerakan IHSG, dan nilai tukar IDR/USD, tetapi tidak ditemukan hubungan kausal antara ketiganya. Perubahan aliran modal asing signifikan mempengaruhi pergerakan IHSG namun tidak signifikan mempengaruhi perubahan nilai tukar IDR/USD. Sedangkan perubahan nilai tukar IDR/USD signifikan mempengaruhi aliran modal asing dan pergerakan IHSG. Adapun pergerakan IHSG tidak signifikan mempengaruhi perubahan aliran modal asing dan nilai tukar IDR/USD.

Dalam penelitian ini, hanya tiga variabel yang diuji (NFP, IHSG, dan KURS) sehingga hasil penelitian tidak sepenuhnya dapat menjelaskan kondisi yang riil terjadi di Indonesia, khususnya mengenai aliran modal asing yang keluar-masuk ke Indonesia. Artinya, aliran modal asing yang keluar-masuk ke Indonesia tidak hanya dijelaskan oleh faktor volatilitas pasar modal dan perubahan nilai tukar, dan begitu pula sebaliknya. Oleh karena itu, bagi penelitian lebih lanjut dapat memasukkan beberapa variabel lainnya yang relevan, seperti perubahan suku bunga jangka pendek dan jangka panjang serta tingkat pertumbuhan perekonomian nasional 
(GNP), dan faktor-faktor makro internasional, seperti perubahan suku bunga internasional dan volatilitas pasar modal global. Untuk mendapatkan uraian yang lebih spesifik terkait dengan masalah tersebut, analisis data juga dapat diarahkan dengan metode semi kuantitatif (perpaduan metode kuantitatif dan kualitatif), sehingga fakta-fakta statistik dapat disinkronisasi dengan aspek-aspek keperilakuan (behavioral finance). 


\section{DAFTAR PUSTAKA}

Abdalla, L.S.A., and Murinde, V. 1997. Exchange Rate and Stock Price Interactions in Emerging Financial Markets: Evidence on India, Korea, Pakistan, and Philippnes. Applied Financial Economics, 7, 25-35.

Agarwal, S., Sheri, F., Chunlin, L., and Ghon, R. 2009. Why do Foreign Investors Underperform Domestic Investors in Trading Activities? Evidence from Indonesia. Journal of Financial Market, 12, 32-53.

Ajayi, R.A., and Mougoue. 1996. On the Dynamic Relation between Stock Price and Exchange Rates. Journal of Financial Research, 19, 193-207.

Bapepam-LK. 2008a. Analisis Hubungan Kointegrasi dan Kausalitas serta Hubungan Dinamis antara Aliran Modal Asing, Perubahan Nilai Tukar, dan Pergerakan IHSG di Pasar Modal Indonesia. Bapepam-LK, Kementerian Keuangan Republik Indonesia. Jakarta. 2008b. Identifikasi Pemodal Asing di Pasar Modal Indonesia. Bapepam-LK, Kementerian Keuangan Republik Indonesia. Jakarta.

2008c. Pengaruh Transaksi Asing terhadap Neraca Pembayaran Indonesia.

Bapepam-LK, Kementerian Keuangan Republik Indonesia. Jakarta.

Bartman, S.M., \& Dufey, G. 2001. International Portfolio Investment: Theory, Evidence, and Institutional Framework. Maastricht University. Maastricht.

Bekaert, G., and Harvey, C.R. 2003. Emerging Market Finance. Journal of Empirical Finance, 10, 3-55.

Bodnar, G.M., and Gentry, W.M. 1993. Exchange Rate Exposure and Industry Characteristics: Evidence from Canada, Japan, and U.S.A. Journal of International Money and Finance, 12, 29-45.

Bohn, H., and Tesar, L. (1996). U.S. Equity Investment in Foreign Market: Portfolio Rebalancing on Return Chasing? American Economic Review, 2, 77-81.

Bursa Efek Indonesia. 2014. IDX Annual Statistick. http://www.idx.co.id. 2014. IDX Monhtly Statistic. http://www.idx.co.id.

2014. IDX Fact Book. http://www.idx.co.id.

Chayawadee, Chai-Anant and Corrine, Ho. 2008. Understanding Asian Equity Flows, Market Returns, and Exchange Rate. Monetary and Rconomic Department, BIS Working Papers, No. 245, Januari 2008. 
Dornbusch, R., and Fischer, S. 1980. Exchange Rates and Current Account. American Economics Review, 70, 960-710.

Dvorak, T. 2005. Do Domestic Investors have an Information Adventage? Evidence from Indonesia. Journal of Finance, 60, 817-839.

Edwards, K. 2000. Foreign Portfolio and Direct Investment: Complementary, Differences, and Integration. OECD Global Forum on International Investment-Attracting Foreign Direct Investment for Development.

Enders, W. 2004. Applied Econometric Times Series, $2^{\text {nd }}$ Eddition. John Wiley and Sons, Inc. New York.

Evans, K. 2002. Foreign Portfolio and Direct Investment: Complementary, Differences, and Integration. OECD Global Forum on International Investment-Attracting Foreign Direct Investment for Development. Shanghai.

Franke, J.A. 1993. Monetary and Portfolio-Balance Models of the Determination of Exchange Rates. MIT Press, Chambridge.

Frensidy, Budi. 2008. Analisis Pengaruh Aksi Beli-Jual Asing, Kurs, dan Indeks Hang Seng terhadap Indeks Harga Saham Gabungan di Bursa Efek Indonesia dengan Model GARCH. Media Riset \& Bisnis, 8, 25-42.

Froot, K.A., and Donohue, J. 2002. The Persistence of Emerging Market Equity Flows. Emerging Market Review, Vol. 3, pp. 511-534.

\& Tarun Ramadorai. 2002. The Information Content of International Portfolio Flows. NBER Working Paper, No. 8472.

He, J., and Ng, L.K. 1998. The Foreign Exchange Exposure of Japanese Multinational Corporations. Journal of Finance, 53, 733-753.

Ibrahim, M.H. 2000. Cointegration and Granger Causality Test of Interaction in Malaysia. Asian Economic Buleten, 17, 36-47.

Jorion, P. 1990. The Exchange Rate Exposure of U.S. Multinationals. Journal of Business, 63, 331-345.

1991. The Pricing of Exchange Rate Risk in Stock Market. Journal of Financial and Quantitative Analysis, 363-376.

Karolyi, A.G. 2002. Did the Asian Financial Crisis Scare Foreign Investors Out of Japan? PasificBasin Finance Journal, 10, 411-442.

Ma, C.K., and Kao, G. 1990. On Exchange Rate Changes and Stock Price Reaction. Journal of Business Finance Review, 60, 668-675. 
Parthapratim Pal. 1998. Foreign Portfolio Investment in India Equity Market: Has the Economy Benefited? Economics and Political Weekly, March 1998, 14-20.

Ramasamy, B., and Mathew, Y. 2001. The Causality between Stock Returns and Exchange Rates: Revisted. Research Paper Series, 11. Division of Business and Management, the University of Nottingham in Malaysia.

Richard, A. 2005. Big Fish in Small Ponds: the Trading Behavior and Price Impact of Foreign Investors in Asian Emerging Equity Markets. Journal of Financial and Quantitative Analysis, $40,1-27$.

Solnik, Bruno. 1974. Why Not Diversify Internationally Reather than Domestically? Financial Analysts Journal, 30, 48-54.

Todaro, M.P., \& Smith, S.C. 2004. Pembangunan Economi Dunia Ketiga. Erlangga. Jakarta.

Wang, J. 2007. Foreign Equity Trading and Emerging Market Volatility: Evidence from Indonesia and Thailand. Journal of Development Economics, 84, 798-811.

Wongbangpo, P., and Sharma, C.S. 2002. Stock Market and Macroeconomic Fundamental Dynamic Interaction: ASEAN-5 Country. Journal of Asian Economics, 13, 27-51. 


\section{LAMPIRAN}

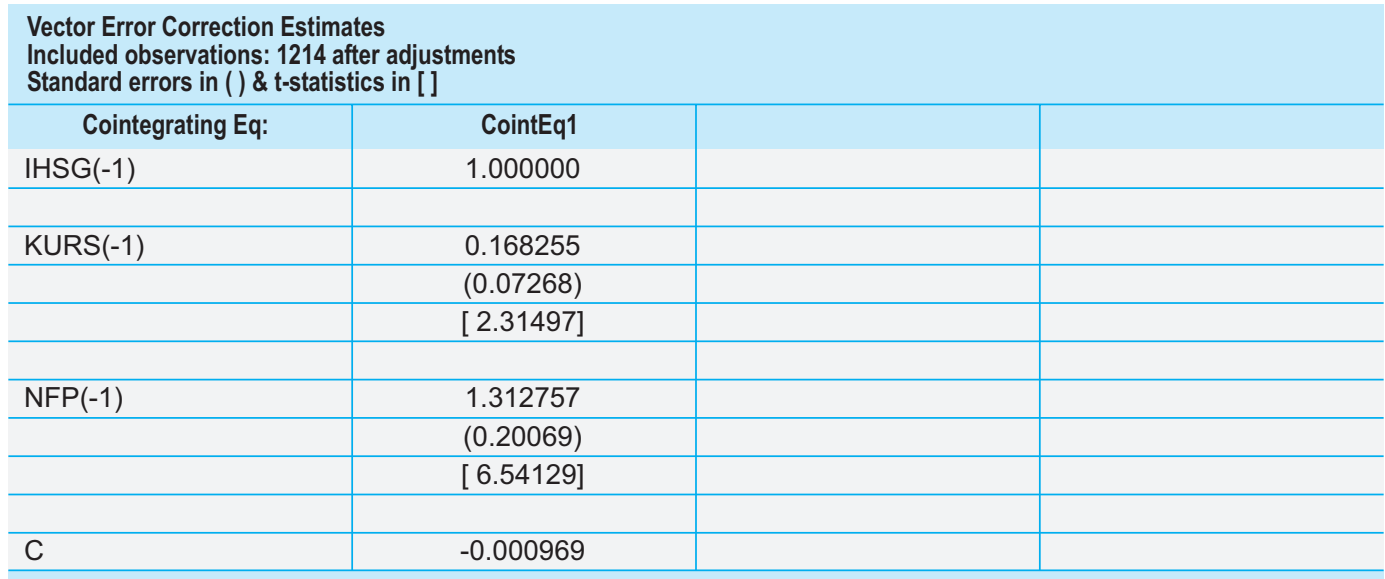




\begin{tabular}{|c|c|c|c|}
\hline Error Correction: & $\mathrm{D}(\mathrm{IHSG})$ & D(KURS) & $\mathrm{D}(\mathrm{NFP})$ \\
\hline \multirow[t]{3}{*}{ CointEq1 } & -1.207046 & -0.144594 & -0.092216 \\
\hline & $(0.10183)$ & $(0.11046)$ & $(0.03894)$ \\
\hline & {$[-11.8536]$} & {$[-1.30901]$} & {$[-2.36841]$} \\
\hline \multirow{3}{*}{$\mathrm{D}(\mathrm{IHSG}(-1))$} & 0.234114 & 0.164658 & 0.073596 \\
\hline & $(0.09546)$ & $(0.10355)$ & $(0.03650)$ \\
\hline & [2.45244] & [1.59009] & [2.01629] \\
\hline \multirow{3}{*}{$\mathrm{D}(\mathrm{IHSG}(-2))$} & 0.238373 & 0.169068 & 0.043339 \\
\hline & $(0.08892)$ & $(0.09646)$ & $(0.03400)$ \\
\hline & [2.68067] & [1.75273] & [1.27464] \\
\hline \multirow{3}{*}{$\mathrm{D}(\mathrm{IHSG}(-3))$} & 0.063798 & 0.125147 & 0.030798 \\
\hline & $(0.08243)$ & $(0.08942)$ & $(0.03152)$ \\
\hline & [0.77395] & [1.39956] & [0.97713] \\
\hline \multirow[t]{3}{*}{$\mathrm{D}(\mathrm{IHSG}(-4))$} & 0.000742 & 0.093415 & 0.013293 \\
\hline & $(0.07444)$ & $(0.08075)$ & $(0.02846)$ \\
\hline & [0.00996] & [1.15682] & [0.46700] \\
\hline \multirow[t]{3}{*}{$\mathrm{D}(\mathrm{IHSG}(-5))$} & 0.014849 & 0.057140 & 0.009643 \\
\hline & $(0.06666)$ & $(0.07231)$ & $(0.02549)$ \\
\hline & {$[0.22276]$} & [0.79020] & [0.37834] \\
\hline \multirow[t]{3}{*}{$\mathrm{D}(\mathrm{IHSG}(-6))$} & -0.060825 & 0.037114 & 0.005027 \\
\hline & $(0.05770)$ & $(0.06259)$ & $(0.02206)$ \\
\hline & {$[-1.05424]$} & [0.59301] & [0.22785] \\
\hline \multirow{3}{*}{$\mathrm{D}(\mathrm{IHSG}(-7))$} & -0.016104 & 0.036535 & 0.005781 \\
\hline & $(0.04825)$ & $(0.05234)$ & $(0.01845)$ \\
\hline & {$[-0.33379]$} & {$[0.69810]$} & [0.31339] \\
\hline \multirow[t]{3}{*}{$\mathrm{D}(\mathrm{IHSG}(-8))$} & -0.018260 & 0.007995 & -0.005848 \\
\hline & $(0.03968)$ & $(0.04304)$ & $(0.01517)$ \\
\hline & {$[-0.46024]$} & {$[0.18576]$} & {$[-0.38550]$} \\
\hline \multirow[t]{3}{*}{$\mathrm{D}(\mathrm{IHSG}(-9))$} & -0.015560 & 0.002083 & -0.004467 \\
\hline & $(0.02844)$ & $(0.03085)$ & $(0.01087)$ \\
\hline & {$[-0.54710]$} & {$[0.06751]$} & {$[-0.41073]$} \\
\hline \multirow[t]{3}{*}{$\mathrm{D}(\mathrm{KURS}(-1))$} & 0.204857 & -0.874490 & 0.007634 \\
\hline & $(0.03089)$ & $(0.03350)$ & $(0.01181)$ \\
\hline & [6.63274] & {$[-26.1014]$} & [0.64646] \\
\hline \multirow[t]{3}{*}{$\mathrm{D}(\mathrm{KURS}(-2))$} & 0.269393 & -0.767726 & -0.003318 \\
\hline & $(0.03808)$ & $(0.04131)$ & $(0.01456)$ \\
\hline & [7.07424] & {$[-18.5852]$} & {$[-0.22785]$} \\
\hline
\end{tabular}




\begin{tabular}{|c|c|c|c|}
\hline Error Correction: & $\mathrm{D}(\mathrm{IHSG})$ & D(KURS) & $D$ (NFP) \\
\hline \multirow[t]{3}{*}{$\mathrm{D}(\mathrm{KURS}(-3))$} & 0.256662 & -0.672575 & -0.010716 \\
\hline & $(0.04242)$ & $(0.04602)$ & $(0.01622)$ \\
\hline & [6.05024] & {$[-14.6157]$} & {$[-0.66065$} \\
\hline \multirow[t]{3}{*}{$\mathrm{D}(\mathrm{KURS}(-4))$} & 0.215838 & -0.572385 & -0.022966 \\
\hline & $(0.04447)$ & $(0.04824)$ & $(0.01700)$ \\
\hline & [4.85324] & {$[-11.8648]$} & {$[-1.35054$} \\
\hline \multirow[t]{3}{*}{$\mathrm{D}(\mathrm{KURS}(-5))$} & 0.216329 & -0.526977 & -0.026768 \\
\hline & $(0.04444)$ & $(0.04821)$ & $(0.01699)$ \\
\hline & [4.86769] & {$[-10.9312]$} & {$[-1.57527$} \\
\hline \multirow[t]{3}{*}{$\mathrm{D}(\mathrm{KURS}(-6))$} & 0.167330 & -0.424954 & -0.023755 \\
\hline & $(0.04374)$ & $(0.04745)$ & $(0.01673)$ \\
\hline & [3.82514] & {$[-8.95538]$} & {$[-1.42024$} \\
\hline \multirow[t]{3}{*}{$\mathrm{D}(\mathrm{KURS}(-7))$} & 0.127630 & -0.325060 & -0.009581 \\
\hline & $(0.04094)$ & $(0.04440)$ & $(0.01565)$ \\
\hline & [3.11786] & {$[-7.32042]$} & {$[-0.61210$} \\
\hline \multirow{3}{*}{$\mathrm{D}(\mathrm{KURS}(-8))$} & 0.076096 & -0.221601 & -0.029000 \\
\hline & $(0.03576)$ & $(0.03879)$ & $(0.01367)$ \\
\hline & [2.12792] & {$[-5.71256]$} & {$[-2.12086$} \\
\hline \multirow{3}{*}{$\mathrm{D}(\mathrm{KURS}(-9))$} & -0.015366 & -0.123914 & -0.030545 \\
\hline & $(0.02677)$ & $(0.02903)$ & $(0.01023)$ \\
\hline & {$[-0.57407]$} & {$[-4.26779]$} & {$[-2.98451$} \\
\hline \multirow{3}{*}{$\mathrm{D}(\mathrm{NFP}(-1))$} & 1.492584 & 0.046816 & -0.873938 \\
\hline & $(0.14501)$ & $(0.15730)$ & $(0.05545)$ \\
\hline & [10.2927] & {$[0.29761]$} & {$[-15.7615$} \\
\hline \multirow{3}{*}{$\mathrm{D}(\mathrm{NFP}(-2))$} & 1.457429 & 0.008642 & -0.848087 \\
\hline & $(0.15300)$ & $(0.16597)$ & $(0.05850)$ \\
\hline & [9.52544] & [0.05207] & {$[-14.4965$} \\
\hline \multirow[t]{3}{*}{$\mathrm{D}(\mathrm{NFP}(-3))$} & 1.340757 & 0.087240 & -0.841922 \\
\hline & $(0.15925)$ & $(0.17275)$ & $(0.06089)$ \\
\hline & [8.41911] & {$[0.50501]$} & {$[-13.8265$} \\
\hline \multirow[t]{3}{*}{$\mathrm{D}(\mathrm{NFP}(-4))$} & 1.216628 & 0.080428 & -0.694316 \\
\hline & $(0.16198)$ & $(0.17571)$ & $(0.06194)$ \\
\hline & [7.51083] & {$[0.45773]$} & {$[-11.2102$} \\
\hline \multirow{3}{*}{$\mathrm{D}(\mathrm{NFP}(-5))$} & 0.923900 & 0.066162 & -0.574435 \\
\hline & $(0.15811)$ & $(0.17151)$ & $(0.06045)$ \\
\hline & [5.84342] & {$[0.38576]$} & {$[-9.50187$} \\
\hline
\end{tabular}




\begin{tabular}{|c|c|c|c|}
\hline Error Correction: & $\mathrm{D}(\mathrm{IHSG})$ & D(KURS) & $\mathrm{D}(\mathrm{NFP})$ \\
\hline \multirow[t]{3}{*}{$\mathrm{D}(\mathrm{NFP}(-6))$} & 0.810392 & 0.174995 & -0.464861 \\
\hline & $(0.14793)$ & $(0.16047)$ & $(0.05656)$ \\
\hline & [5.47822] & [1.09053] & {$[-8.21852]$} \\
\hline \multirow[t]{3}{*}{$\mathrm{D}(\mathrm{NFP}(-7))$} & 0.724648 & 0.328032 & -0.336553 \\
\hline & $(0.13086)$ & $(0.14195)$ & $(0.05004)$ \\
\hline & [5.53762] & [2.31090] & [-6.72630] \\
\hline \multirow[t]{3}{*}{$\mathrm{D}(\mathrm{NFP}(-8))$} & 0.242928 & 0.164902 & -0.217840 \\
\hline & $(0.11083)$ & $(0.12023)$ & $(0.04238)$ \\
\hline & [2.19182] & [1.37158] & {$[-5.14032]$} \\
\hline \multirow[t]{3}{*}{$\mathrm{D}(\operatorname{NFP}(-9))$} & 0.150721 & 0.063579 & -0.094500 \\
\hline & $(0.07842)$ & $(0.08506)$ & $(0.02998)$ \\
\hline & [1.92204] & {$[0.74743]$} & {$[-3.15170]$} \\
\hline \multirow[t]{3}{*}{ C } & $5.01 \mathrm{E}-06$ & $2.36 \mathrm{E}-06$ & $-6.37 E-06$ \\
\hline & $(0.00033)$ & $(0.00036)$ & $(0.00013)$ \\
\hline & {$[0.01507]$} & {$[0.00654]$} & {$[-0.05018]$} \\
\hline R-squared & 0.523112 & 0.460991 & 0.512990 \\
\hline Adj. R-squared & 0.511844 & 0.448255 & 0.501482 \\
\hline Sum sq. resids & 0.158690 & 0.186730 & 0.023201 \\
\hline S.E. equation & 0.011572 & 0.012553 & 0.004425 \\
\hline F-statistic & 46.42358 & 36.19569 & 44.57904 \\
\hline Log likelihood & 3705.493 & 3606.729 & 4872.619 \\
\hline Akaike AIC & -6.056825 & -5.894116 & -7.979603 \\
\hline Schwarz SC & -5.934957 & -5.772248 & -7.857734 \\
\hline Mean dependent & $-1.26 \mathrm{E}-05$ & 8.99E-08 & $-2.11 \mathrm{E}-06$ \\
\hline S.D. dependent & 0.016563 & 0.016900 & 0.006267 \\
\hline \multicolumn{2}{|c|}{ Determinant resid covariance (dof adj.) } & $4.09 \mathrm{E}-13$ & \\
\hline \multicolumn{2}{|c|}{ Determinant resid covariance } & $3.81 \mathrm{E}-13$ & \\
\hline \multicolumn{2}{|c|}{ Log likelihood } & 12190.62 & \\
\hline \multicolumn{2}{|c|}{ Akaike information criterion } & -19.93513 & \\
\hline \multicolumn{2}{|c|}{ Schwarz criterion } & -19.55692 & \\
\hline
\end{tabular}


Estimation Proc:

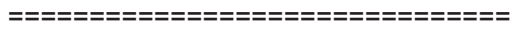

EC(NOCONST,C,1) 19 IHSG KURS NFP

VAR Model:

$\mathrm{D}(\mathrm{IHSG})=\mathrm{A}(1,1)^{*}\left(\mathrm{~B}(1,1)^{*} \mathrm{IHSG}(-1)+\mathrm{B}(1,2)^{*} \mathrm{KURS}(-1)+\mathrm{B}(1,3)^{*} \mathrm{NFP}(-1)+\mathrm{B}(1,4)\right)+\mathrm{C}(1,1)^{*} \mathrm{D}(\mathrm{IHSG}(-1))+$ $\mathrm{C}(1,2)^{*} \mathrm{D}(\mathrm{IHSG}(-2))+\mathrm{C}(1,3)^{*} \mathrm{D}(\mathrm{IHSG}(-3))+\mathrm{C}(1,4)^{*} \mathrm{D}(\mathrm{IHSG}(-4))+\mathrm{C}(1,5)^{*} \mathrm{D}(\mathrm{IHSG}(-5))+\mathrm{C}(1,6)^{*} \mathrm{D}(\mathrm{IHSG}(-6))+$ $\mathrm{C}(1,7)^{\star} \mathrm{D}(\mathrm{IHSG}(-7))+\mathrm{C}(1,8)^{\star} \mathrm{D}(\mathrm{IHSG}(-8))+\mathrm{C}(1,9)^{\star} \mathrm{D}(\mathrm{IHSG}(-9))+\mathrm{C}(1,10)^{*} \mathrm{D}(\mathrm{KURS}(-1))+\mathrm{C}(1,11)^{*} \mathrm{D}(\mathrm{KURS}(-2))+$ $\mathrm{C}(1,12)^{\star} \mathrm{D}(\mathrm{KURS}(-3))+\mathrm{C}(1,13)^{*} \mathrm{D}(\mathrm{KURS}(-4))+\mathrm{C}(1,14)^{*} \mathrm{D}(\mathrm{KURS}(-5))+\mathrm{C}(1,15)^{\star} \mathrm{D}(\mathrm{KURS}(-6))+$ $\mathrm{C}(1,16)^{*} \mathrm{D}(\mathrm{KURS}(-7))+\mathrm{C}(1,17)^{*} \mathrm{D}(\mathrm{KURS}(-8))+\mathrm{C}(1,18)^{*} \mathrm{D}(\mathrm{KURS}(-9))+\mathrm{C}(1,19)^{*} \mathrm{D}(\mathrm{NFP}(-1))+$ $\mathrm{C}(1,20)^{*} \mathrm{D}(\mathrm{NFP}(-2))+\mathrm{C}(1,21)^{*} \mathrm{D}(\mathrm{NFP}(-3))+\mathrm{C}(1,22)^{*} \mathrm{D}(\mathrm{NFP}(-4))+\mathrm{C}(1,23)^{*} \mathrm{D}(\mathrm{NFP}(-5))+\mathrm{C}(1,24)^{*} \mathrm{D}(\mathrm{NFP}(-6))+$ $C(1,25)^{*} \mathrm{D}(\mathrm{NFP}(-7))+\mathrm{C}(1,26)^{*} \mathrm{D}(\mathrm{NFP}(-8))+\mathrm{C}(1,27)^{*} \mathrm{D}(\mathrm{NFP}(-9))+\mathrm{C}(1,28)$

$\mathrm{D}(\mathrm{KURS})=\mathrm{A}(2,1)^{*}\left(\mathrm{~B}(1,1)^{*} \mathrm{IHSG}(-1)+\mathrm{B}(1,2)^{*} \mathrm{KURS}(-1)+\mathrm{B}(1,3)^{*} \mathrm{NFP}(-1)+\mathrm{B}(1,4)\right)+\mathrm{C}(2,1)^{*} \mathrm{D}(\mathrm{IHSG}(-1))+$ $\mathrm{C}(2,2)^{*} \mathrm{D}(\mathrm{IHSG}(-2))+\mathrm{C}(2,3)^{*} \mathrm{D}(\mathrm{IHSG}(-3))+\mathrm{C}(2,4)^{*} \mathrm{D}(\mathrm{IHSG}(-4))+\mathrm{C}(2,5)^{*} \mathrm{D}(\mathrm{IHSG}(-5))+\mathrm{C}(2,6)^{*} \mathrm{D}(\mathrm{IHSG}(-6))+$ $\mathrm{C}(2,7)^{*} \mathrm{D}(\mathrm{IHSG}(-7))+\mathrm{C}(2,8)^{*} \mathrm{D}(\mathrm{IHSG}(-8))+\mathrm{C}(2,9)^{*} \mathrm{D}(\mathrm{IHSG}(-9))+\mathrm{C}(2,10)^{*} \mathrm{D}(\mathrm{KURS}(-1))+\mathrm{C}(2,11)^{*} \mathrm{D}(\mathrm{KURS}(-2))+$ $C(2,12)^{*} \mathrm{D}(\mathrm{KURS}(-3))+\mathrm{C}(2,13)^{*} \mathrm{D}(\mathrm{KURS}(-4))+\mathrm{C}(2,14)^{*} \mathrm{D}(\mathrm{KURS}(-5))+\mathrm{C}(2,15)^{*} \mathrm{D}(\mathrm{KURS}(-6))+$ $\mathrm{C}(2,16)^{*} \mathrm{D}(\mathrm{KURS}(-7))+\mathrm{C}(2,17)^{*} \mathrm{D}(\mathrm{KURS}(-8))+\mathrm{C}(2,18)^{*} \mathrm{D}(\mathrm{KURS}(-9))+\mathrm{C}(2,19)^{*} \mathrm{D}(\mathrm{NFP}(-1))+$ $C(2,20)^{*} D(N F P(-2))+C(2,21)^{*} D(N F P(-3))+C(2,22)^{*} D(N F P(-4))+C(2,23)^{*} D(N F P(-5))+C(2,24)^{*} D(N F P(-6))+$ $C(2,25)^{*} D(N F P(-7))+C(2,26)^{*} D(N F P(-8))+C(2,27)^{*} D(N F P(-9))+C(2,28)$

$\mathrm{D}(\mathrm{NFP})=\mathrm{A}(3,1)^{*}\left(\mathrm{~B}(1,1)^{*} \mathrm{IHSG}(-1)+\mathrm{B}(1,2)^{*} \mathrm{KURS}(-1)+\mathrm{B}(1,3)^{*} \mathrm{NFP}(-1)+\mathrm{B}(1,4)\right)+\mathrm{C}(3,1)^{*} \mathrm{D}(\mathrm{IHSG}(-1))+$ $\mathrm{C}(3,2)^{*} \mathrm{D}(\mathrm{IHSG}(-2))+\mathrm{C}(3,3)^{*} \mathrm{D}(\mathrm{IHSG}(-3))+\mathrm{C}(3,4)^{*} \mathrm{D}(\mathrm{IHSG}(-4))+\mathrm{C}(3,5)^{*} \mathrm{D}(\mathrm{IHSG}(-5))+\mathrm{C}(3,6)^{*} \mathrm{D}(\mathrm{IHSG}(-6))+$ $\mathrm{C}(3,7)^{*} \mathrm{D}(\mathrm{IHSG}(-7))+\mathrm{C}(3,8)^{*} \mathrm{D}(\mathrm{IHSG}(-8))+\mathrm{C}(3,9)^{*} \mathrm{D}($ IHSG $(-9))+\mathrm{C}(3,10)^{*} \mathrm{D}(\mathrm{KURS}(-1))+\mathrm{C}(3,11)^{*} \mathrm{D}(\mathrm{KURS}(-2))+$ $\mathrm{C}(3,12)^{*} \mathrm{D}($ KURS $(-3))+\mathrm{C}(3,13)^{*} \mathrm{D}(\mathrm{KURS}(-4))+\mathrm{C}(3,14)^{*} \mathrm{D}(\mathrm{KURS}(-5))+\mathrm{C}(3,15)^{*} \mathrm{D}(\mathrm{KURS}(-6))+$ $\mathrm{C}(3,16)^{*} \mathrm{D}(\mathrm{KURS}(-7))+\mathrm{C}(3,17)^{*} \mathrm{D}(\mathrm{KURS}(-8))+\mathrm{C}(3,18)^{*} \mathrm{D}(\mathrm{KURS}(-9))+\mathrm{C}(3,19)^{*} \mathrm{D}(\mathrm{NFP}(-1))+$ $C(3,20)^{*} D(N F P(-2))+C(3,21)^{*} D(N F P(-3))+C(3,22)^{*} D(N F P(-4))+C(3,23)^{*} D(N F P(-5))+C(3,24)^{*} D(N F P(-6))+$ $C(3,25)^{*} D(N F P(-7))+C(3,26)^{*} D(N F P(-8))+C(3,27)^{*} D(N F P(-9))+C(3,28)$ 
VAR Model - Substituted Coefficients:

=ニニニニニニニニニニニニニニニニニニニニニニニニニニニニ=

$\mathrm{D}(\mathrm{IHSG})=-1.20704629031^{*}\left(\mathrm{IHSG}(-1)+0.16825515883^{*} \mathrm{KURS}(-1)+1.31275677022^{*} \mathrm{NFP}(-1)-\right.$ $0.000968664562027)+0.234113938155^{*} \mathrm{D}(\mathrm{IHSG}(-1))+0.238373024714^{*} \mathrm{D}(\mathrm{IHSG}(-2))+$ $0.0637984073889 * \mathrm{D}(\mathrm{IHSG}(-3))+0.000741801990208 * \mathrm{D}(\mathrm{IHSG}(-4))+0.0148493499708 * \mathrm{D}(\mathrm{IHSG}(-5))-$ $0.0608250159712 * \mathrm{D}(\mathrm{IHSG}(-6))-0.01610387832 * \mathrm{D}(\mathrm{IHSG}(-7))-0.0182604382391 * \mathrm{D}(\mathrm{IHSG}(-8))-$ $0.0155602028577^{*} \mathrm{D}($ IHSG $(-9))+0.204857449031$ * $\mathrm{D}(\mathrm{KURS}(-1))+0.269393399585^{*} \mathrm{D}(\mathrm{KURS}(-2))+$ $0.256661581322^{*} \mathrm{D}(\mathrm{KURS}(-3))+0.215837747065^{*} \mathrm{D}(\mathrm{KURS}(-4))+0.216328844076 * \mathrm{D}(\mathrm{KURS}(-5))+$ $0.167330082535 * \mathrm{D}(\mathrm{KURS}(-6))+0.127629651451 * \mathrm{D}(\mathrm{KURS}(-7))+0.076096354912 * \mathrm{D}(\mathrm{KURS}(-8))-$ $0.0153657218093^{*} \mathrm{D}(\mathrm{KURS}(-9))+1.49258390341^{*} \mathrm{D}(\mathrm{NFP}(-1))+1.45742910062 * \mathrm{D}(\mathrm{NFP}(-2))+$ $1.34075749527{ }^{\star} \mathrm{D}(\mathrm{NFP}(-3))+1.21662774196{ }^{\star} \mathrm{D}(\mathrm{NFP}(-4))+0.923899871437{ }^{\star} \mathrm{D}(\mathrm{NFP}(-5))+$ $0.810391967914 * \mathrm{D}(\mathrm{NFP}(-6))+0.724647598234{ }^{*} \mathrm{D}(\mathrm{NFP}(-7))+0.242928440213^{*} \mathrm{D}(\mathrm{NFP}(-8))+$ $0.150721043657^{*} \mathrm{D}(\mathrm{NFP}(-9))+5.00629671065 \mathrm{e}-06$

$\mathrm{D}(\mathrm{KURS})=-0.144593705456^{*}\left(\mathrm{IHSG}(-1)+0.16825515883^{*} \mathrm{KURS}(-1)+1.31275677022^{*} \mathrm{NFP}(-1)-\right.$ $0.000968664562027)+0.164658024998^{*} \mathrm{D}(\mathrm{IHSG}(-1))+0.169067925585^{\star} \mathrm{D}(\mathrm{IHSG}(-2))+$ $0.125147198508 * \mathrm{D}(\mathrm{IHSG}(-3))+0.0934151967656$ * $($ IHSG $(-4))+0.0571398446652 * \mathrm{D}(\mathrm{IHSG}(-5))+$ $0.0371138476936 * \mathrm{D}(\mathrm{IHSG}(-6))+0.0365349647312 * \mathrm{D}(\mathrm{IHSG}(-7))+0.00799470563789 * \mathrm{D}(\mathrm{IHSG}(-8))+$ $0.00208279483169 * D(I H S G(-9))-0.874490366381 * D(K U R S(-1))-0.767725868168 * D(K U R S(-2))-$ $0.672575035586{ }^{*} \mathrm{D}(\mathrm{KURS}(-3))-0.572385114251 * \mathrm{D}(\mathrm{KURS}(-4))-0.526976752859 * \mathrm{D}(\mathrm{KURS}(-5))-$ $0.424954465748 * \mathrm{D}(\mathrm{KURS}(-6))-0.325059781502 * \mathrm{D}(\mathrm{KURS}(-7))-0.221600630389 * \mathrm{D}(\mathrm{KURS}(-8))-$ $0.123914249303^{*} \mathrm{D}(\mathrm{KURS}(-9))+0.0468157229865^{*} \mathrm{D}(\mathrm{NFP}(-1))+0.00864195119996{ }^{*} \mathrm{D}(\mathrm{NFP}(-2))+$ $0.0872401874505^{\star} \mathrm{D}(\mathrm{NFP}(-3))+0.080427989745^{\star} \mathrm{D}(\mathrm{NFP}(-4))+0.0661622918623^{*} \mathrm{D}(\mathrm{NFP}(-5))+$ $0.174995424241{ }^{*} \mathrm{D}(\mathrm{NFP}(-6))+0.328031876829 * \mathrm{D}(\mathrm{NFP}(-7))+0.164901902632 * \mathrm{D}(\mathrm{NFP}(-8))+$ $0.0635787375646^{*} \mathrm{D}(\mathrm{NFP}(-9))+2.35532810589 \mathrm{e}-06$

$\mathrm{D}(\mathrm{NFP})=-0.0922161479002^{*}\left(\mathrm{IHSG}(-1)+0.16825515883^{*} \mathrm{KURS}(-1)+\right.$ $1.31275677022 * N F P(-1)-0.000968664562027)+0.0735963572088 * D(I H S G(-1))+$ $0.0433385333233^{*} \mathrm{D}(\mathrm{IHSG}(-2))+0.030798174387^{*} \mathrm{D}(\mathrm{IHSG}(-3))+0.0132925364003^{*} \mathrm{D}(\mathrm{IHSG}(-4))+$ $0.00964324775396 * \mathrm{D}(\mathrm{IHSG}(-5))+0.00502654498212^{*} \mathrm{D}(\mathrm{IHSG}(-6))+0.00578127252444 * \mathrm{D}(\mathrm{IHSG}(-7))-$ $0.00584816413691^{*} \mathrm{D}(\mathrm{IHSG}(-8))-0.00446655738886^{*} \mathrm{D}(\mathrm{IHSG}(-9))+0.0076344243721^{*} \mathrm{D}(\mathrm{KURS}(-1))-$ $0.00331769830874 * \mathrm{D}(\mathrm{KURS}(-2))-0.0107160723119^{*} \mathrm{D}(\mathrm{KURS}(-3))-0.022965568366 * \mathrm{D}(\mathrm{KURS}(-4))-$ $0.026768321193{ }^{*} \mathrm{D}(\mathrm{KURS}(-5))-0.0237554778096^{*} \mathrm{D}(\mathrm{KURS}(-6))-0.00958051358078{ }^{*} \mathrm{D}(\mathrm{KURS}(-7))$ $-0.0289997687541^{*} \mathrm{D}(\mathrm{KURS}(-8))-0.0305445841396^{\star} \mathrm{D}(\mathrm{KURS}(-9))-0.873938486405^{\star} \mathrm{D}(\mathrm{NFP}(-1))-$ $0.848086973838^{*} \mathrm{D}(\mathrm{NFP}(-2))-0.841921659708^{*} \mathrm{D}(\mathrm{NFP}(-3))-0.694316371319^{*} \mathrm{D}(\mathrm{NFP}(-4))$ $-0.574434513597^{\star} \mathrm{D}(\mathrm{NFP}(-5))-0.464861088937^{\star} \mathrm{D}(\mathrm{NFP}(-6))-0.33655315667^{\star} \mathrm{D}(\mathrm{NFP}(-7))-$ $0.217840080012^{*} \mathrm{D}(\mathrm{NFP}(-8))-0.0944996336936^{*} \mathrm{D}(\mathrm{NFP}(-9))-6.37363328153 e-06$ 
432 Buletin Ekonomi Moneter dan Perbankan, Volume 17, Nomor 4, April 2015

Halaman ini sengaja dikosongkan 